PNL- -8335

DE93 004892

\title{
Application of Three Aquifer Test Methods for Estimating Hydraulic Properties Within the 100-N Area
}

\author{
T. J Gilmore \\ F. A. Spane, Jr. \\ D. R. Newcomer \\ C. R. Sherwood
}

December 1992

Prepared for

the U.S. Department of Energy

under Contract DE-AC06-76RLO 1830

Pacific Northwest Laboratory

Richland, Washington 99352 


\section{Executive Summary}

This study was conducted for the U.S. Department of Energy by Pacific Northwest Laboratory at the request of the Westinghouse Hanford Company, Facilities Operations Division. The purpose of the study was to better define the range of saturated horizontal hydraulic conductivities in the 100-N Area of the Hanford Site in southeastern Washington for use in a numerical groundwater model.

Three methods were used for determining aquifer properties and are discussed within this report 1) reanalysis of past pumping test data using a pressure derivative method to identify the data in the radial flow regime for analysis by traditional graphical techniques, 2) sinusoidal analysis techniques described in Ferris $(1952,1963)$ that utilize water-table responses to river-level variations, and 3) the basic flow equation for groundwater.

Based on the results obtained from these three methods, the $100-\mathrm{N}$ Area was divided into two areas with higher hydraulic conductivities in the northeast and lower hydraulic conductivities in the southwest.

A best estimate range of hydraulic conductivity values may be obtained by using the Ferris (composite well/time-lag analysis) and aquifer test reanalysis methods to form the upper bound of the range, and the flow equation and Ferris (composite well/apparent tidal efficiency analysis) method for the lower bound of the range. The hydraulic conductivities in the southwest region of 100-N Area range from 36 to $73 \mathrm{ft} / \mathrm{d}$ and in the northeast region 280 to $325 \mathrm{ft} / \mathrm{d}$. The range of hydraulic conductivity presented in this report has narrowed the previous range (104 ft/d to 8,400 $\mathrm{ft} / \mathrm{d}$ ) for the $100-\mathrm{N}$ Area that was based on previous pumping test results. 


\section{Acknowledgments}

This technical report was prepared for the Westinghouse Hanford Company, Facilities Operations Division. Technical peer review was provided by P. D. Thorne Pacific Northwest Laboratory and A. L. Law (Westinghouse Hanford Company) with editorial review and guidance provided by W. R. Gorst and J. B. Flynn. 


\section{Conitents}

Executive Summary $\ldots \ldots \ldots \ldots \ldots \ldots \ldots \ldots \ldots \ldots \ldots \ldots \ldots \ldots \ldots \ldots \ldots$ iii

Acknowledgments $\ldots \ldots \ldots \ldots \ldots \ldots \ldots \ldots \ldots \ldots \ldots \ldots \ldots \ldots \ldots \ldots$ 'v

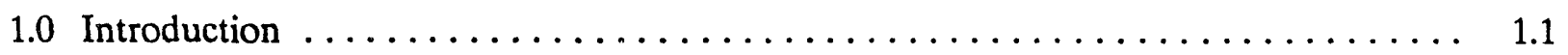

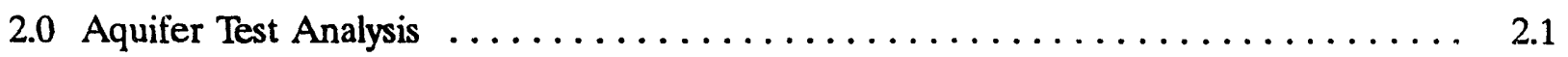

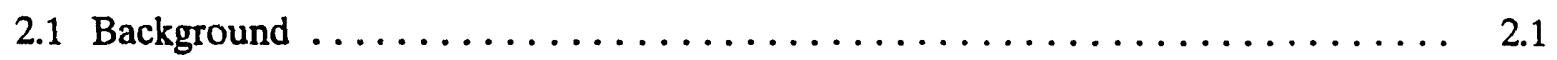

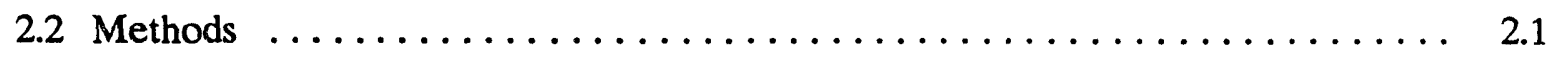

3.0 Ferris Method for Aquifer Parameter Estimation $\ldots \ldots \ldots \ldots \ldots \ldots \ldots \ldots \ldots$

4.0 Aquifer Parameter Estimation Using the Groundwater Flow Equation $\ldots \ldots \ldots \ldots$

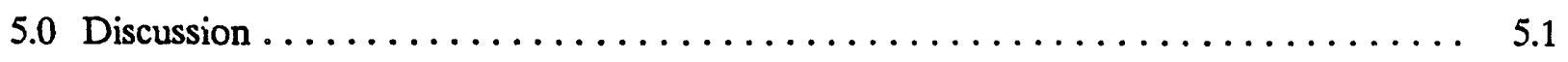

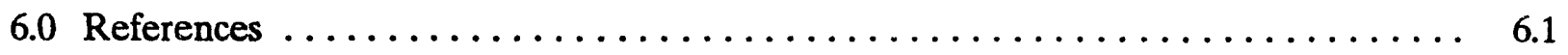

Appendix A - Aquifer Test of Well $199-\mathrm{N}-32 \ldots \ldots \ldots \ldots \ldots \ldots \ldots \ldots \ldots \ldots \ldots \ldots$

Appendix B - Computer Cole for Aquifer Parameter Estimation $\ldots \ldots \ldots \ldots \ldots \ldots$. . . . 


\section{Figures}

1.1 Location Map of Monitoring Wells in the $100-\mathrm{N}$ Area $\ldots \ldots \ldots \ldots \ldots \ldots \ldots$

3.1 Cross Section of Geology Parallel to the Columbia River $\ldots \ldots \ldots \ldots \ldots \ldots .2$

3.2 Columbia River Fluctuation (a) with Well N-8s Hydrograph

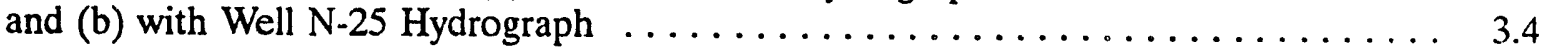

3.3 Well Water-Level Changes Versus Change in River-Stage Slope of Regression Line

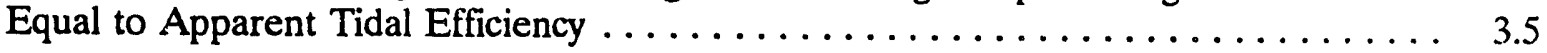

3.4 Composite Analysis Results for Time Lag Method $\ldots \ldots \ldots \ldots \ldots \ldots \ldots$

3.5 Composite Analysis Results for Apparent Tidal Efficiency $\ldots \ldots \ldots \ldots \ldots \ldots \ldots$

3.6 Composite Well Analysis Results for Time Lag Method Using Well N-8s as Point

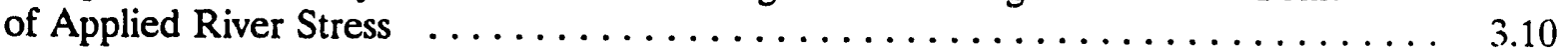

3.7 Composite Well Analysis Results for Apparent Tidal Efficiency Using Well N-8s as

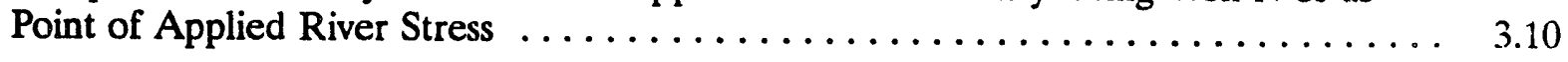

4.1 Comparison of Observed and Predicted Water Levels for Well N-8s $\ldots \ldots \ldots \ldots$

\section{Tables}

3.1 Summary of Well Hydrograph/River-Stage Analysis $\ldots \ldots \ldots \ldots \ldots \ldots \ldots \ldots$

3.2 Summary of Well Hydrograph/River-Stage (Well N-8s) Analysis $\ldots \ldots \ldots \ldots$

$4.1 \mathrm{~N}$ Area Flow Equation Method Diffusivity $\ldots \ldots \ldots \ldots \ldots \ldots \ldots \ldots \ldots \ldots$

$5.1 \mathrm{~N}$ Area Diffusivity, Flow Equation and Ferris Method $\ldots \ldots \ldots \ldots \ldots \ldots \ldots$

viii 


\subsection{Introduction}

To predict the flux of strontium-90 entering the Columbia River, the Westinghouse Hanford Company developed a numerical simulation of ${ }^{90} \mathrm{Sr}$ transport for the 100-N Area on the Hanford Site in southeastern Washington using the PORFLO-3 code (Connelly et al. 1991). One of the input parameters for the numerical model, saturated horizontal conductivity, was based on aquifer pumping test data from wells $\mathrm{N}-27, \mathrm{~N}-32$, and $\mathrm{N}-34$ (Connelly et al. 1991): The aquifer test results yielded a wide range of hydraulic conductivities from 129 to $577 \mathrm{ft} / \mathrm{d}(39.3$ to $176 \mathrm{~m} / \mathrm{d})$. Following calibration of the model, a value of $220 \mathrm{ft} / \mathrm{d}(67 \mathrm{~m} / \mathrm{d})$ was used.

In order to increase confidence in the numerical model results, additional hydraulic characterization of the system in the $100-\mathrm{N}$ Area was needed. Three methods to determine aquifer parameters were used to determine which might provide additional information for narrowing the current range of values and providing verification of the input parameters for the numerical model.

The reliability of a groundwater flow model's results rests largely on the knowledge of the hydraulic characteristics of the aquifer. A widely used method for determining aquifer parameters is the constant-rate pumping test. A pumping test consists of pumping groundwater from a well at a constant rate and monitoring the effects on groundwater levels. These effects are analyzed by comparison to theoretical flow equations, often using manual graphical analysis to determine . aquifer parameters, primarily transmissivity (T) and storage coefficient (S). Hydraulic conductivity $(\mathrm{K})$ can then be determined from $\mathrm{T}$ by dividing by the aquifer thickness.

In addition to the standard pumping tests, there are several analytical methods for estimating aquifer diffusivity (the ratio of transmissivity to the storage coefficient) from the aquifer water-level responses to fluctuation in nearby surfacewater bodies (i.e., rivers, oceans, etc.) Published methods of determining aquifer characteristics from groundwater-level response to river or tide fluctuations rely on analytical or semi-analytical solutions to simplified hydraulic equations. All of the methods assume that the aquifer is semi-infinite (bounded on one side by the fluctuating water body) and has no mean gradient. The Ferris $(1952,1963)$ methods assume purely sinusoidal fluctuations, as do Gregg (1966), Carr and Van der Kamp (1969), and Erskine (1992). Cooper and Rorabaugh (1963) derived a solution for a damped sinusoid to better represent river-level changes during a flood event, and Pinder et al. (1969) provide a semi-analytical method for summing the instantaneous response to small changes in river level, which allows accurate representation of arbitrary river-level changes. Other methods for evaluating aquifer properties from well response to flood-wave events have been presented by Rowe (1960) as modified by Hantush (1961) and Reynolds (1987). 
The study described in this report used three methods to determine aquifer properties: 1) analysis of pumping-test data using pressure-derivative diagnostics, 2) evaluation of river-induced groundwater changes with the Ferris (1963) method, and 3) evaluation of river-induced changes using a flow equation method that numerically solves the one-dimensional continuity equation. Data for both waterand river-level were collected from a network of groundwater monitoring wells at the 100-N Area (Figure 1.1) and are reported in Gilmore et al. $(1989,1990)$.

The first method used was the reanalysis of data from past aquifer pumping tests to determine transmissivity values. There have been at least 13 aquifer pumping tests run in the $100-\mathrm{N}$ Area. The results of these pumping tests were reviewed. Tests that were determined to be most representative were reanalyzed using pressure derivative diagnostic plots that can identify which data are in the radial flow regime and can be analyzed by additional graphical techniques to determine transmissivity values. The results of these analysis are presented in Section 2.0. Two analytical methods using the groundwater response to river-level changes were applied to the $100-\mathrm{N}$ data for both a comparison with the pumping test data and to provide for a spatially weighted hydraulic characterization. The first method uses the analytical method described in Ferris $(1952,1963)$ (Section 3.0) and the second method uses the continuity equation for flow (Bear 1979, p. 113) (Section 4.0). A discussion (Section 5.0) follows the descriptions of each of the three analysis techniques. 


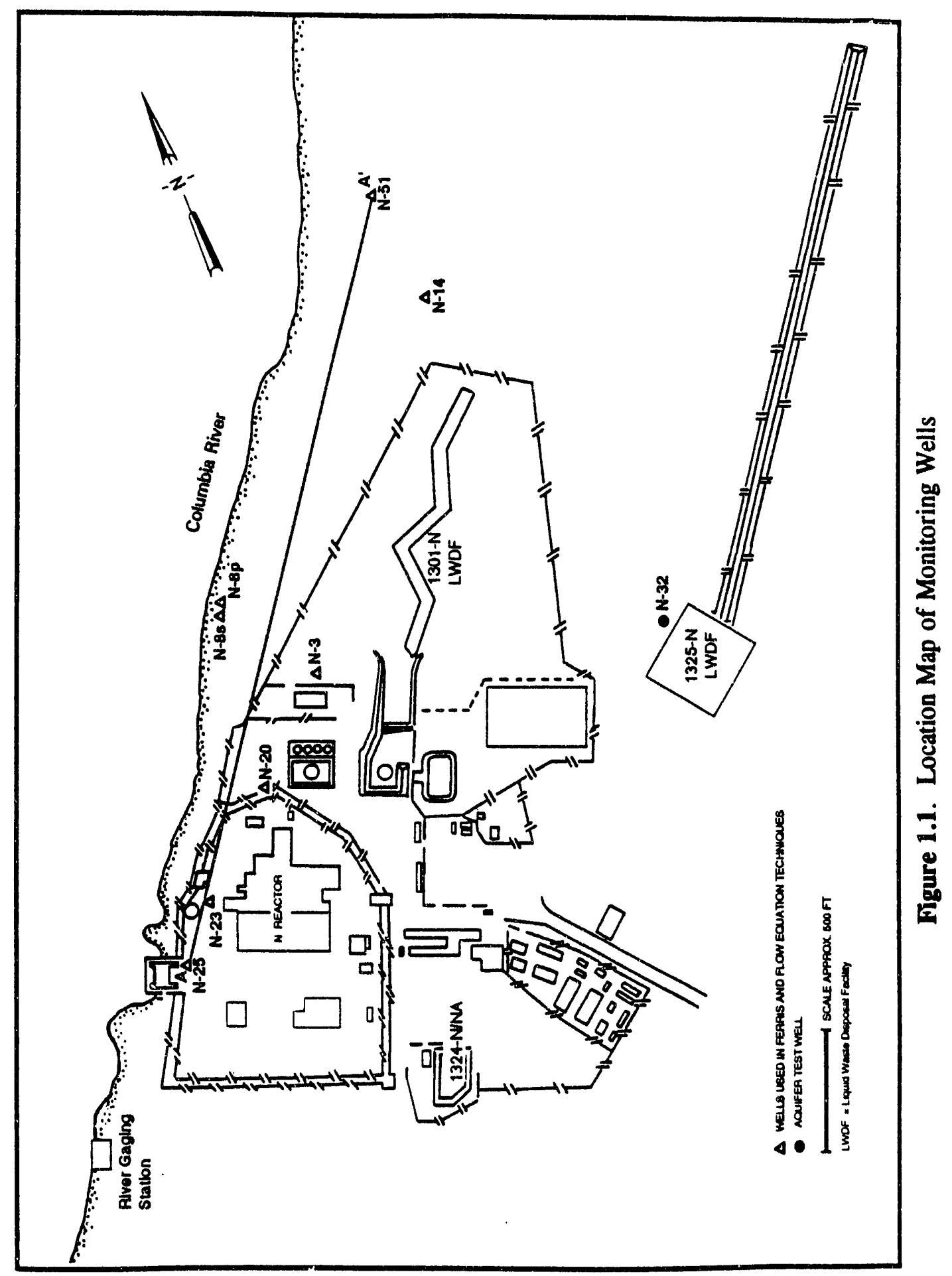




\subsection{Aquifer Test Analysis}

\subsection{Background}

Estimates of hydraulic properties of the unconfined aquifer in the $100-\mathrm{N}$ Area are reported in Kipp and Mudd (1973) and PNL (1988). Estimates of transmissivity ranged between $5200 \mathrm{ft}^{2} / \mathrm{d}$ to $420,000 \mathrm{ft}^{2} / \mathrm{d}$ and estimates of hydraulic conductivity ranged between $92 \mathrm{ft} / \mathrm{d}$ and $5300 \mathrm{ft} / \mathrm{d}$, varying by a factor of approximately 50. These estimates were calculated using data from tests conducted in wells 199-N-14, 199-N-15, 199-N-27, 199-N-32, 199-N-34, 199-N-39, 199-N-64, $199-\mathrm{N}-67,199-\mathrm{N}-69$, and 199-N-70. The data from wells $199-\mathrm{N}-69$ and $199-\mathrm{N}-70$ were taken from an unreleased 1989 report by PNL researchers T. J Gilmore, S. M. Goodwin, and D. R. Newcomer.

These estimates were derived by applying log-log type curve matching methods (e.g., Theis 1935) or the Jacob (1946) straight-line solution to pumping-test data. These tests ranged in duration from a few hours to 24 hours of pumping and the discharge rates ranged from a few gallons per minute to as much as $153 \mathrm{gpm}$. These variations of discharge rates and test duration are due in part to the variability of hydraulic properties within the aquifer, but are also reflective of lack of consistency in pumping test design.

\subsection{Methods}

A cursory review of previous hydraulic test analysis of well tests conducted in the area indicates that the majority of the reported property estimates (i.e., $\mathrm{T}$ and $\mathrm{K}$ ) are not strictly valid. The lack of validity in the previous analyses is attributed to a variety of adverse test conditions that were evident in the reviewed test data, as well as reliance on invalid analytical assumptions that were applied in the data analysis. These adverse test conditions and assumptions include the:

- nearby presence of the Columbia River that acts as a recharge boundary during hydraulic testing

- effects of waste-water disposal at nearby facilities (e.g., 1325-N and 1301-N cribs) and the surface disposal of groundwater pumped during constant-rate pumping tests

- assumption that Theisian test conditions held during testing (e.g., fully penetrating well, homogeneous confined aquifer of infinite extent, etc.)

- short-duration of many of the tests that did not extend into late-time radial flow conditions 
- the lack of test data corrections for unconfined aquifer dewatering and partial penetration effects, and

- misapplication of $\log -\log$ and semi-log, straight-line analysis solutions for test data not displaying radial flow conditions.

The following briefly highlights several sources of error associated with previous hydraulic test analysis within $100-\mathrm{N}$ Area wells.

Hydraulic analysis of constant-rate pumping tests are usually performed using log-log type-curve matching and/or semi-log, straight-line methods. During the reanalysis of selected pumping test results, a number of analysis errors were identified. For example, hydraulic conductivity estimates provided in Kipp and Mudd (1973) from single-well tests conducted in wells 199-N-14 and 199-N-15 are based on log-log, type-curve analysis of pumping test drawdown and recovery data. The log-log, type-curve matching method, however, is only strictly correct for analysis of observation well test response (i.e., multiple-well interference tests). Quantitative $\log -\log$ analysis of the test response at the pumping well is not completely valid, since a number of factors contribute to drawdown and recovery that are not normally accounted for in the analytical procedure. These nonformational response phenomena that affect water-level response at the pumping well include wellbore storage, formation damage or stimulation due to drilling/well construction practices, pumping variations, partial aquifer penetration, etc. (e.g., Weeks 1979; Earlougher 1977).

Another identified cause for the wide range in cited hydraulic conductivity values is the inappropriate application of straight-line analysis. The use of the Jacob (1946) straight-line analysis for pumping test data is strictly valid only for test data exhibiting radial flow conditions and for test times that satisfy the prescribed time, $t$, criteria specified in the following relationship:

$$
t \geq\left(r^{2} S\right) /(4 T \mu)
$$

where $\mathbf{r}=$ effective well radius (for pumping well analysis)

$\mathrm{S}=$ storativity

$\mathrm{T}=$ transmissivity

$\mu=$ dimensionless parameter equal to 0.01 .

In reviewing the original data sets and analysis by various workers in the 100-N Area, a number of misapplications of the straight-line analysis method were identified for test data not exhibiting radial flow conditions or satisfying the $\mu$ criteria relationship. Recent developments in log-log diagnostic analysis have greatly facilitated the identification of the test data that can properly be analyzed using straight-line analysis methods. These recently developed diagnostic methods rely on converting pumping drawdown and recovery pressure data to derivative form and analyzing the shape of the pressure derivative versus time on a log-log 
diagnostic plot. As noted by others (e.g., Bourdet and Alagoa 1984, Clark and Golg-Racht 1985), pressure derivative diagnostic plots can be used to precisely identify regions within the pumping test data set that are controlled by nonformational (e.g., wellbore storage, skin effects, etc.) and formational factors (homogeneous vs. heterogeneous formation response, radial flow conditions, etc.).

Pumping test data from well 199-N-32 were the only data selected to be reanalyzed for hydraulic property determination. Hydraulic properties could not be estimated for other tests in the 100-N Area because of the reasons previously cited.

A 24-hr constant-rate pumping test was conducted at well 199-N-32 in March 1984, shortly after well completion. Discharge rates varied during the course of the test, and averaged approximately $100 \mathrm{gpm}$. Data records indicate (i.e., as suggested by recoverying water levels) that the well was still developing during the later stages of the pumping test. Because of the discharge rate variability and presence of well development during the test, drawdown test data were not reanalyzed. Recovery test data for well 199-N-32 following termination of pumping, however, were reanalyzed utilizing the methods described in Spane (1992). Briefly described, the analysis procedure included the following steps:

- Diagnostic analysis of the recovery water-level response using a log-log pressure change and pressure change derivative plot.

- Quantitative semi-log analysis of the radial flow portion of the recovery water-level data record, as indicated from the log-log pressure derivative plot.

Recovery data were corrected for unconfined aquifer de-watering using the procedure presented in Jacob (1963). Partial penetration effects were evaluated with applicable software presented in Walton (1987). The analysis indicated that partial-penetration effects were relatively constant during the radial flow period of the test data and, therefore, of no significant consequence to the straight-line analysis of test data exhibiting radial fiow conditions. Results of the straight-line analysis indicate a transmissivity of 5,640 ft. Details of the test and reanalysis, including test plots, are presented in Appendix A. 


\subsection{Ferris Method for Aquifer Parameter Estimation}

This section presents the estimates of hydraulic diffusivity for the unconfined aquifer using the analytical method described in Ferris $(1952,1963)$. The use of sinusoidal analysis techniques is detailed for analysis of river-induced well hydrograph responses for selected unconfined aquifer wells in the $100-\mathrm{N}$ Area. Wells exhibiting discernable river-induced sinusoidal responses are shown on the map in Figure 1.1. In all, eight wells were identified, which are located at distances between $80 \mathrm{ft}$ and $440 \mathrm{ft}$ from the river. All but two of the wells (N-3 and $\mathrm{N}-8 \mathrm{p}$ ) are completed with well screen sections at the top of the unconfined aquifer. Figure 3.1 shows a schematic of the well screen sections within the unconfined aqrif $:$ for wells analyzed in this investigation. The unconfined aquifer ranges from approximately 50 to $65 \mathrm{ft}$ thick in the region where the wells are located.

The theoretical basis of the analytical solution of Ferris $(1952,1963)$ requires that the river-stage response can be successfully approximated by a sinusoidal wave, which dissipates with distance from the rivershore boundary. Ferris $(1952,1963)$ presents two analytical methods for calculating aquifer diffusivity (the ratio of transmissivity to the storage coefficient) based on correlating observation well response to river-stage variation. The two techniques include the time-lag and stage-ratio (i.e., apparent tidal efficiency) methods. The two equations, which are based on analogous heat flow equations (Carslaw and Jaeger 1959), permit calculation of the change in groundwater level for a given distance from the river and for a given aquifer diffusivity.

The time-lag and stage-ratio data can be analyzed collectively. In this situation, the ratio of the well stage to river stage (stage ratio method) or time-lag (time-lag method) calculated for each observation well site is plotted versus distance to the river. A best-fit straight line is then constructed through the data and the appropriate match-point information used in the analysis equations provided in Ferris $(1952,1963)$ to calculate the average areal hydraulic diffusivity for the aquifer in this region. If the aquifer storativity $(S)$ is independently known (or can be reliably estimated) then estimates for transmissivity (T) can also be determined by dividing the diffusivity by $\mathrm{S}$.

Implicit assumptions in the Ferris sinusoidal analysis method are that 1) the river fluctuation can be closely approximated by a sinusoidal pattern, 2) the aquifer is homogeneous, 3) the river fully penetrates the aquifer and 4) no significant vertical ground-water flow components are present. To ensure that the first assumption was correct, river-stage data between November 1989 and September 1991 were reviewed to identify a period of cyclic sinusoidal fluctuations. Because 


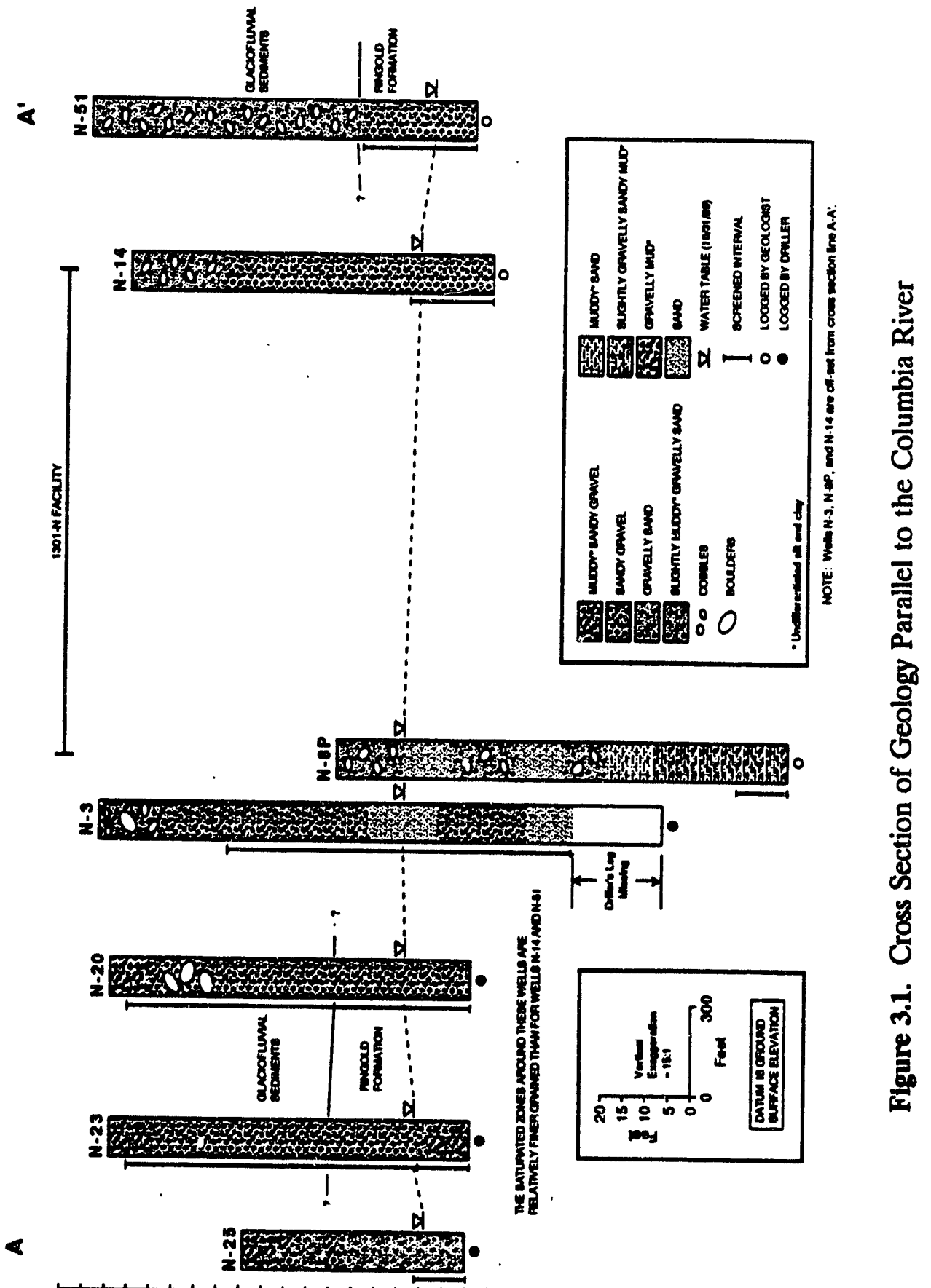

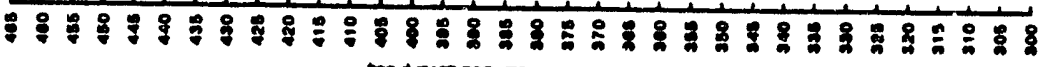


of the highly regulated nature of the Columbia River, extended periods of cyclical river-stage fluctuation patterns are not common. Daily cyclical patterns, however, appear to be more frequent between October and December.

Assumption 2 is a common condition for applying most standard hydrologic analytical methods. Because of the nature of the alluvial deposits comprising the unconfined aquifer on the Hanford Site, heterogeneities are expected to occur with increasing size of the area investigated. In an effort to minimi the effects of heterogeneity, wells examined in this study were all located in pruxımity to the river (i.e., within $450 \mathrm{ft}$ ) and, in most cases, completed in the upper-section of the aquifer (see Figure 3.1).

Assumption 3 implies that river and groundwater exchange occurs immediately, with no delay or attenuation of the induced respr $\therefore$ In most cases this probably does not occur, and is evident on composite time-iag or observed tidal efficiency vs. distance plots for the wells analyzed. In these situations, Ferris (1963) states that a reference well adjacent to the river may be used for calculating the actual river-stage response transmitted to the aquifer, thereby improving the estimation capabilities. For this investigation, river-stage and reference-well responses were used in the analysis of monitoring well hydrograph patterns.

Assumption 4 is probably valid for situations in which monitor wells that are used in the hydraulic property assessment are not located immediately adjacent to the river and/or completed in a thick aquifer. For this investigation, wells were located between $80 \mathrm{ft}$ and $\mathbf{4 4 0} \mathrm{ft}$ from the river and had shallow completions. These conditions would minimize the presence of significant vertical groundwater flow components.

Hourly water-level measurements for the respective wells and the river are generally available for the period December 1989 to February 1991. As indicated, most wells have only limited periods of uninterrupted continuous record. For the analysis, an effort was made to find time periods that were 1) continuous periods without interruption, 2) common with other wells, and 3) reflective of Columbia River stage-elevation data that could be approximated by daily cyclical behavior. Based on these data screening criteria, two time pariods (December 30-31, 1989, and October 18-21, 1990) were selected for analysis of well hydrograph response. Figure 3.2 shows an example of the Columbia River fluctuation pattern and associated well hydrograph response for selected wells during these two time periods. As indicated, the well hydrograph responses exhibit a slightly delayed (lagged) and attenuated signal in comparison to the river-stage behavior.

The general analysis procedure consisted of using computer software to shift the river-stage record by specified increments of time (i.e., time-lag) and then statistically analyzing the correlation of the river-stage and well hydrograph records. The correlation method followed the procedure described in Clark 

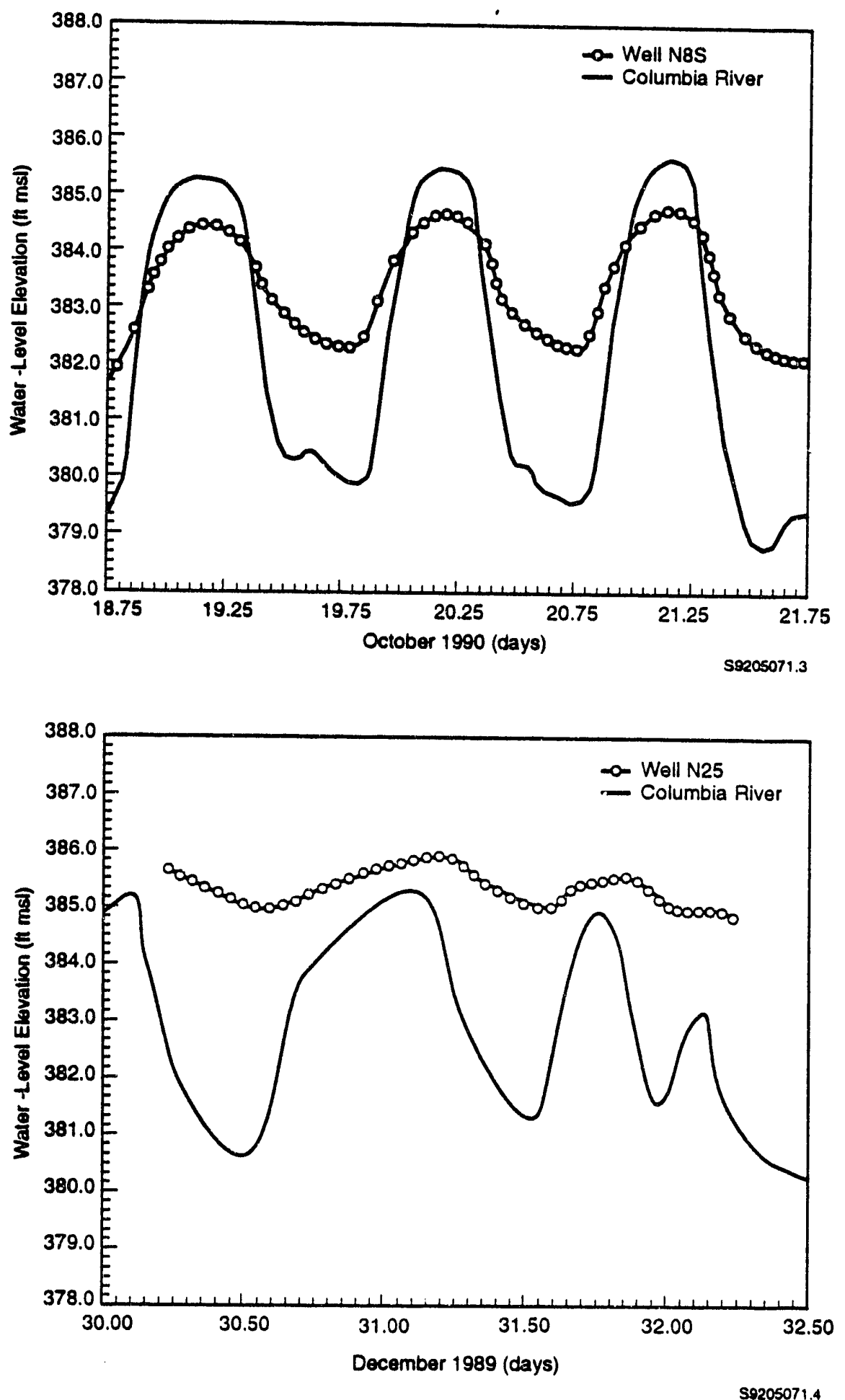

Figure 3.2. Columbia River Fluctuation (a) with Well N-8s Hydrograph and (b) with Well N-25 Hydrograph 
(1967), which was originally developed for calculation of the analogous well barometric efficiency factor based on correlated atmospheric pressure and well water-level changes. For this investigation, the Clark (1967) method was used for determining the apparent tidal efficiency factor $\left(\mathrm{TE}_{\mathrm{a}}\right)$, which was based on relating changes of hourly river-stage elevation with hourly well water-level measurements. The method outlined in Clark (1967) is superior to the peak-ratio method described in Ferris (1963), because it can account for the effects of extraneous trends (such as aquifer recharge) and reduce the effect of individual data errors.

The calculated time-lag for each well analyzed was designated as the value that provided the highest linear correlation coefficient and lowest standard error of estimate for the river-stage and well water-level change correlation. Figure 3.3 shows a final analysis figure for one of the analyzed wells. Included in the figure are results of the statistical analysis for the specified time-lag. As indicated, the apparent tidal efficiency, $\mathrm{TE}_{\mathrm{a}}$, is equal to the slope of the linear regression fit to well water-level changes versus the change in river-stage.

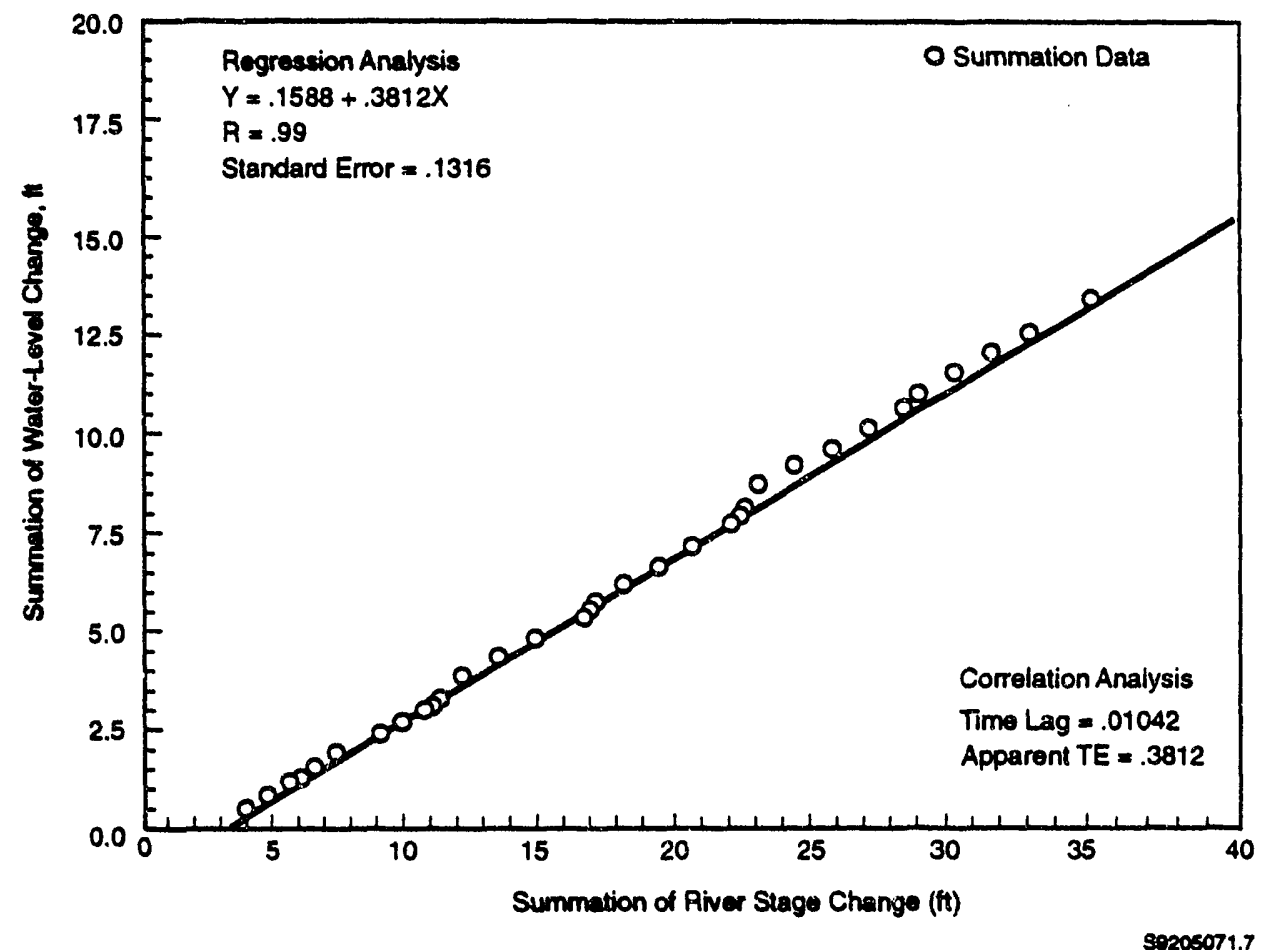

Figure 3.3. Well Water-Level Changes Versus Change in River-Stage. Slope of Regression Line Equal to Apparent Tidal Efficiency $\left(\mathrm{TE}_{\mathrm{a}}\right)$. 
After the $\mathrm{T}_{\mathrm{L}}$ and $\mathrm{TE}_{\mathrm{a}}$ were calculated for each well, the hydraulic diffusivity, $\mathrm{T} / \mathrm{S}$, for the intervening aquifer materials between the observation well and the river were determined using the following relationships presented in Erskine (1991):

Time Lag

$$
\left.T_{L}=x\left[\left(t_{0} S\right) / 4 \pi T\right)\right]^{1 / 2}
$$

or re-arranging

$$
T / S=\left(x^{2} t_{0}\right) /\left(T_{L}^{2} 4 \pi\right)
$$

\section{Apparent Tidal Efficiency}

$$
\mathrm{TE}_{\mathrm{a}}=\exp \left(-\mathrm{x}\left[(\pi \mathrm{S}) /\left(\mathrm{t}_{\mathrm{o}} \mathrm{T}\right)\right]^{1 / 2}\right)
$$

or re-arranging

$$
\mathrm{T} / \mathrm{S}=\left(\mathrm{x}^{2} \pi\right) / \mathrm{t}_{\mathrm{o}}\left(\ln \mathrm{TE} \mathrm{E}_{\mathrm{a}}\right)^{2}
$$

where $\mathrm{x}=$ distance from river to well location

$t_{0}=$ period of river-stage sinusoidal fluctuation.

Time-lag and tidal efficiency calculation results for each well analysis are presented in Table 3.1. Included in the table are estimates for hydraulic diffusivity that are based on both the time-lag method (Equation 2) and apparent tidal efficiency method (Equation 3 ). Considerable variability exists for the estimates of hydraulic diffusivity, which range over 3 orders of magnitude based on time-lag calculations, but only over 1 order of magnitude from apparent tidal efficiency determinations. Additionally, the wells have been grouped into their spatial location as shown in Figure 3.1. Wells N-3, N-8p, N-8s, N-20, N-23, and N-25 comprise a group of wells located along the southwest section of the A - A' crosssectional line (see Figure 3.2), while wells N-14 and N-51 are approximately 1700 and 2200 feet, respectively, to the northeast. The northeast pair of wells have. generally higher diffusivity values than wells in the southwest group.

Time-lag and tidal efficiency calculation results of Table 3.1 were also analyzed collectively by plotting the calculated time-lag or apparent tidal efficiency for each observation well versus distance to the river and constructing a best-fit straight line through the data. With the appropriate match-point information, Equations 2 and 3 were used to calculate the average areal aquifer diffusivity. 
Table 3.1. Summary of Well Hydrograph/River-Stage Analysis

\begin{tabular}{|c|c|c|c|c|c|}
\hline & & & & $\begin{array}{c}\text { Diffusivity } \\
\mathrm{T} / \mathrm{S}\end{array}$ & $\begin{array}{l}\text { Estimate } \\
2 / d)\end{array}$ \\
\hline Well ' & $\begin{array}{c}\text { Distance } \\
\text { From } \\
\text { River (ft) }\end{array}$ & $\begin{array}{c}\text { Time } \\
\text { Lag } \\
\text { (day) } \\
\end{array}$ & $\begin{array}{c}\text { Apparent } \\
\text { TE } \\
\end{array}$ & Time Lag & $\begin{array}{c}\text { Apparent } \\
\text { TE } \\
\end{array}$ \\
\hline Southw & st Group & ells & & & \\
\hline N-3 & 300 & .3313 & .00705 & 65,270 & 11,520 \\
\hline $\mathrm{N}-8 \mathrm{p}$ & 80 & .006944 & .1798 & $10,560,000$ & 6,830 \\
\hline $\mathrm{N}-8 \mathrm{~s}$ & 80 & .01042 & .3812 & $4,691,000$ & 21,614 \\
\hline $\mathrm{N}-20$ & 190 & .1250 & .04543 & 183,900 & 11,870 \\
\hline $\mathrm{N}-23$ & 330 & .2854 & .02714 & 106,400 & 26,290 \\
\hline $\mathrm{N}-25$ & 130 & .06042 & .1793 & 368,400 & $\underline{17,980}$ \\
\hline Compos & ite Analysi & & & 49,890 & 20,620 \\
\hline Northes & st Group & ells & & & \\
\hline $\mathrm{N}-14$ & 440 & .2479 & .01943 & 250,700 & 39,160 \\
\hline N-51 & 320 & .01736 & .1264 & $27,040,000$ & 75,220 \\
\hline
\end{tabular}

(a) Figure 3.4-3.5.

Figures 3.4 and 3.5 show the composite analysis results for time-lag and apparent tidal efficiency, respectively. The least-squares regression line shown in each figure is representative only of wells comprising the southwest group and, therefore, are not reflective of results obtained for wells $\mathrm{N}-14$ and N-51. Composite analysis was not attempted for the two northeast wells, because of the presence of only two wells for this region. Their results, however, are shown for comparison purposes with wells analyzed for the southwest cross-sectional area. As indicated in Figures 3.4 and 3.5, hydraulic diffusivity estimates for the unconfined aquifer in this region based on composite time-lag and apparent tidal efficiency analysis are $49,890 \mathrm{ft}^{2} / \mathrm{d}$ and $20,620 \mathrm{ft}^{2} / \mathrm{d}$, respectively.

Ideally, the least-squares regression line would be expected to pass through the origin. The fact that the regression lines shown in Figures 3.4 and 3.5 have negative y-intercept values suggests that the river "acts" as if it is closer to the wells analyzed. Site inspection of the shoreline in the 100-N Area reveals the possibility that because of manmade modifications (rip-rap emplacement, etc.) the shoreline may be actually closer than surface-distance measurements would indicate (i.e., in some locations 20 to $30 \mathrm{ft}$ closer).

To examine the effects of decreasing the river distance, the well hydrograph data were reanalyzed using well $\mathrm{N}-8 \mathrm{~s}$ to simulate the river response. This caused a reduction of $80 \mathrm{ft}$ in the calculated distance for monitoring wells to the "river." 


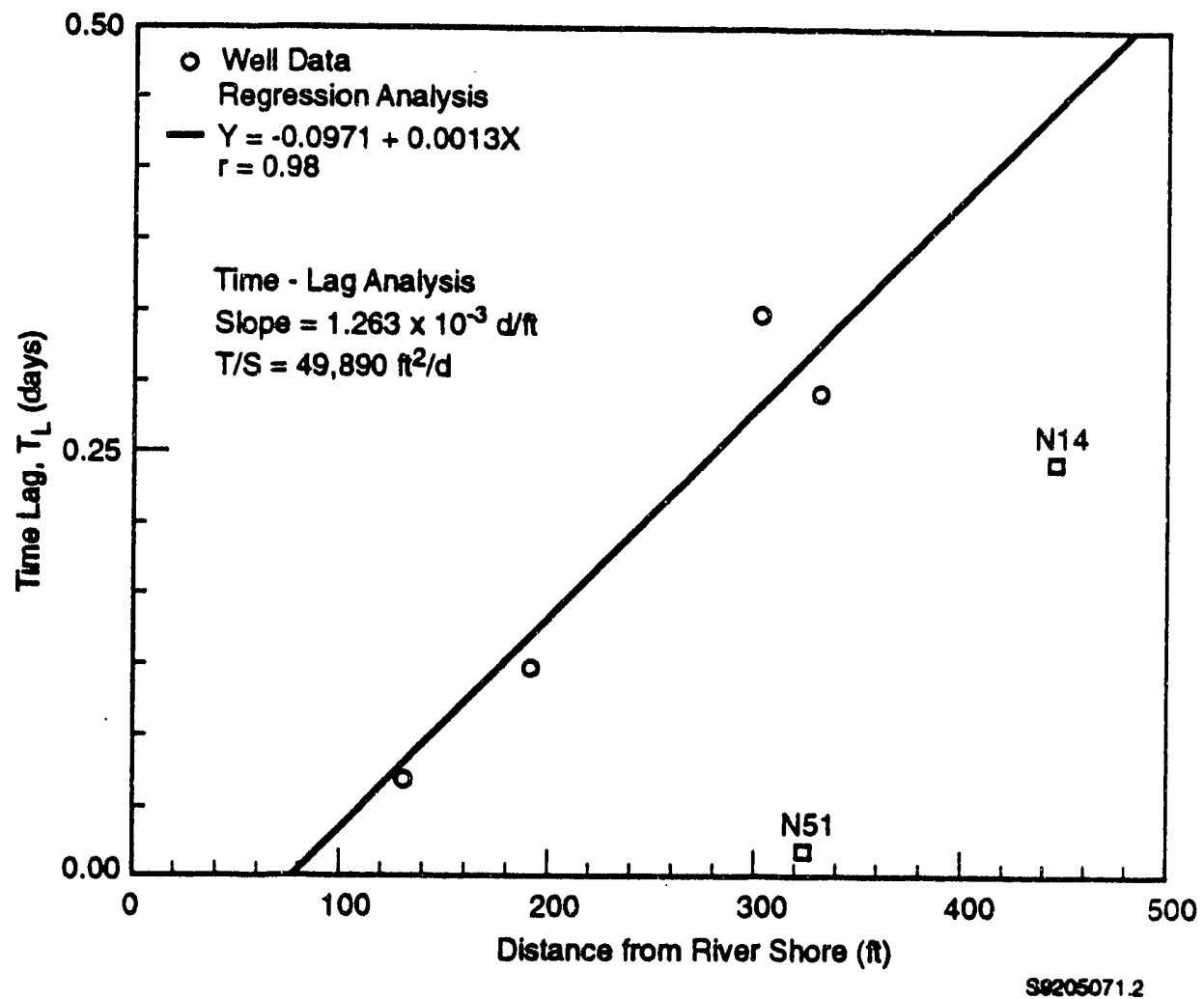

Figure 3.4. Composite Analysis Results for Time Lag Method

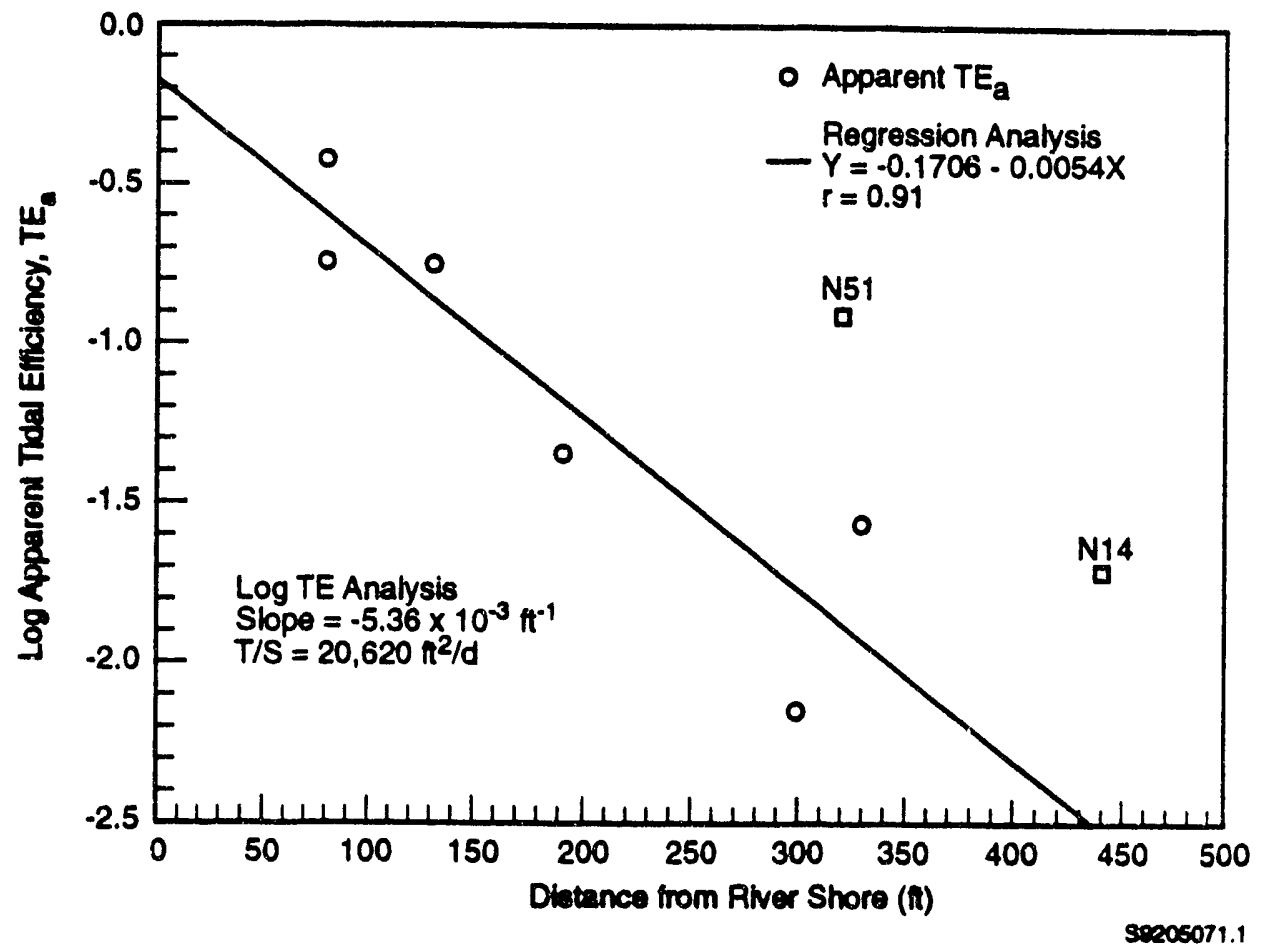

Figure 3.5. Composite Analysis Results for Apparent Tidal Efficiency $\left(\mathrm{TE}_{\mathrm{a}}\right)$ 
The use of a reference well to simulate river response is also the preferred procedure to use for those situations where the river does not completely penetrate the aquifer (e.g., Reynolds 1987). Results of the reanalysis are presented in Table 3.2. (Note: Wells $\mathrm{N}-8 \mathrm{~s}$ and $\mathrm{N}-8 \mathrm{p}$ cannot be analyzed because in this procedure they represent the shoreline). As indicated in Table 3.2, the variability in hydraulic diffusivity estimates was reduced significantly, especially for estimates calculated using the time-lag method. Of particular importance is the more close corroboration for hydraulic diffusivity values obtained with the two methods (i.e., except for well $\mathrm{N}-51$ ). In most cases, hydraulic diffusivity estimates were within a factor of about four for each well.

Figures 3.6 and 3.7 show the composite well analysis results for the time-lag and apparent tidal efficiency methods, using well $\mathrm{N}-8 \mathrm{~s}$ as the point of applied river stress. As previously stated, wells $\mathrm{N}-14$ and $\mathrm{N}-51$ were not used in the composite analysis and are shown only for comparison purposes. Exarnination of Figures 3.5 and 3.7 indicates that similar average hydraulic diffusivity values were obtained from the composite analysis of apparent tidal efficiency vs. distance (i.e., comparing the river derived values vs. that obtained using well $\mathrm{N}-8 \mathrm{~s}$ as the river stress). A slightly lower average value for the southwest region, however, was obtained based on the composite time-lag analysis (i.e., $36,480 \mathrm{ft}^{2} / \mathrm{d}$ vs. $49,890 \mathrm{ft}^{2} / \mathrm{d}$ ), as shown in Figures 3.4 and 3.6.

Table 3.2. Summary of Well Hydrograph/River-Stage (Well N-8s) Analysis

\begin{tabular}{|c|c|c|c|c|c|}
\hline \multirow[b]{2}{*}{ Well } & \multirow{2}{*}{$\begin{array}{c}\text { Distance } \\
\text { From River } \\
\left(\mathrm{ft}^{(\mathrm{a})}\right) \\
\end{array}$} & \multirow{2}{*}{$\begin{array}{c}\text { Time } \\
\text { Lag } \\
\text { (day) }\end{array}$} & \multirow[b]{2}{*}{$\begin{array}{c}\text { Apparent } \\
\text { TE } \\
\end{array}$} & \multicolumn{2}{|c|}{$\begin{array}{c}\text { Diffusivity Estimate } \\
\mathrm{T} / \mathrm{S}\left(\mathrm{ft}^{2} / \mathrm{d}\right) \\
\end{array}$} \\
\hline & & & & $\begin{array}{l}\text { Time } \\
\text { Lag } \\
\end{array}$ & $\begin{array}{c}\text { Apparent } \\
\text { TE } \\
\end{array}$ \\
\hline \multicolumn{6}{|c|}{ Southwest Group Wells } \\
\hline$N-3$ & 220 & .3604 & .01598 & 29,650 & 8,890 \\
\hline $\mathrm{N}-20$ & 110 & .1063 & .1368 & 85,290 & 9,600 \\
\hline $\mathrm{N}-23$ & 250 & .3000 & .06649 & 55,260 & 26,730 \\
\hline$N-25$ & 50 & .05958 & .4512 & 56,040 & 12,400 \\
\hline \multicolumn{4}{|c|}{ Composite Analysis $^{(b)}$} & 36,480 & 20,010 \\
\hline \multicolumn{6}{|c|}{ Northeast Group Wells } \\
\hline $\mathrm{N}-14$ & 360 & .2196 & .05530 & 213,900 & 48,590 \\
\hline N-51 & 240 & .00625 & .3310 & $117,300,000$ & 147,980 \\
\hline
\end{tabular}

(a) Calculated distance to river reduced by $80 \mathrm{ft}$ distance to well $\mathrm{N}-8 \mathrm{~s}$.

(b) Figure 3.6-3.7 


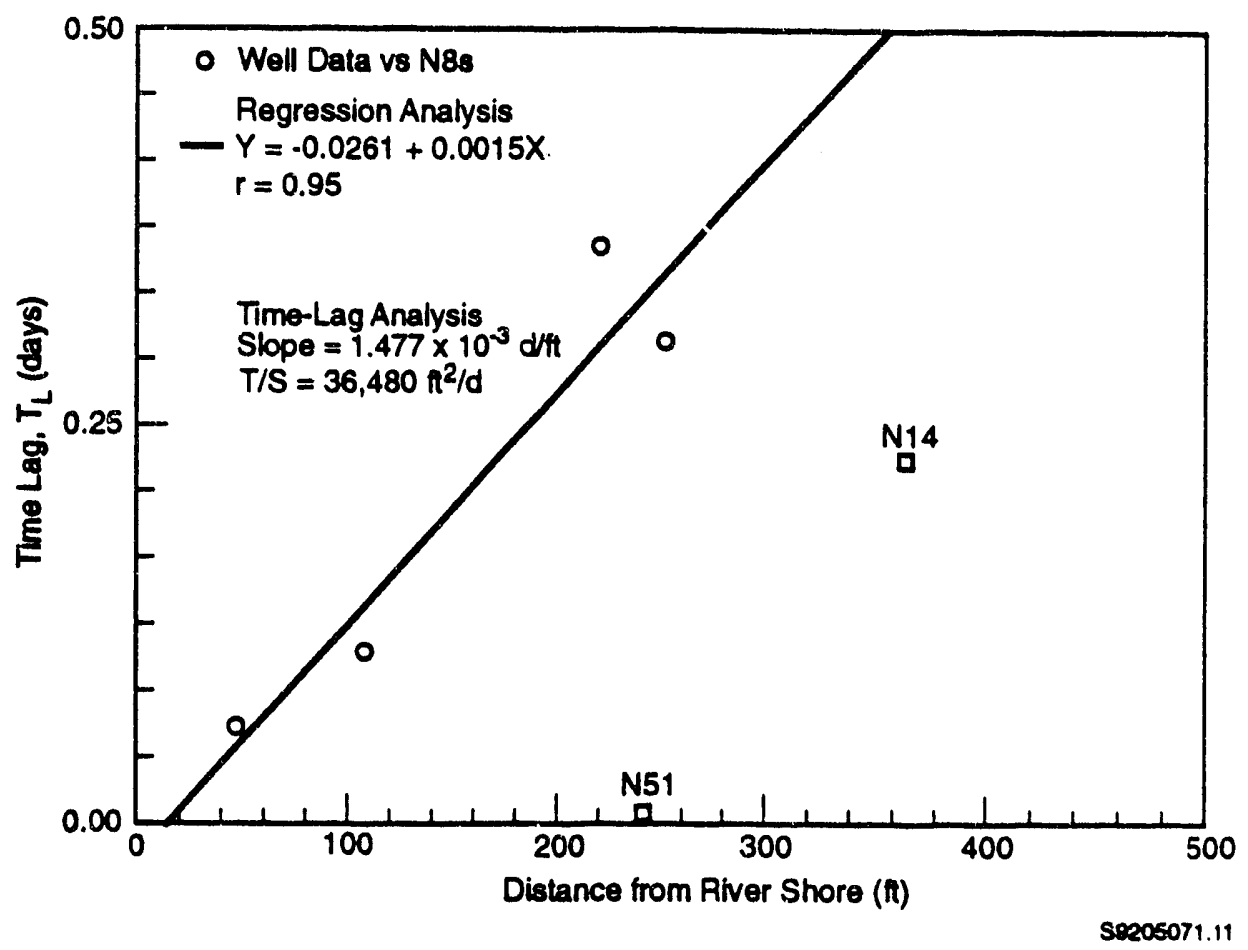

Figure 3.6. Composite Well Analysis Results for Time Lag Method Using Well N-8s as Point of Applied River Stress

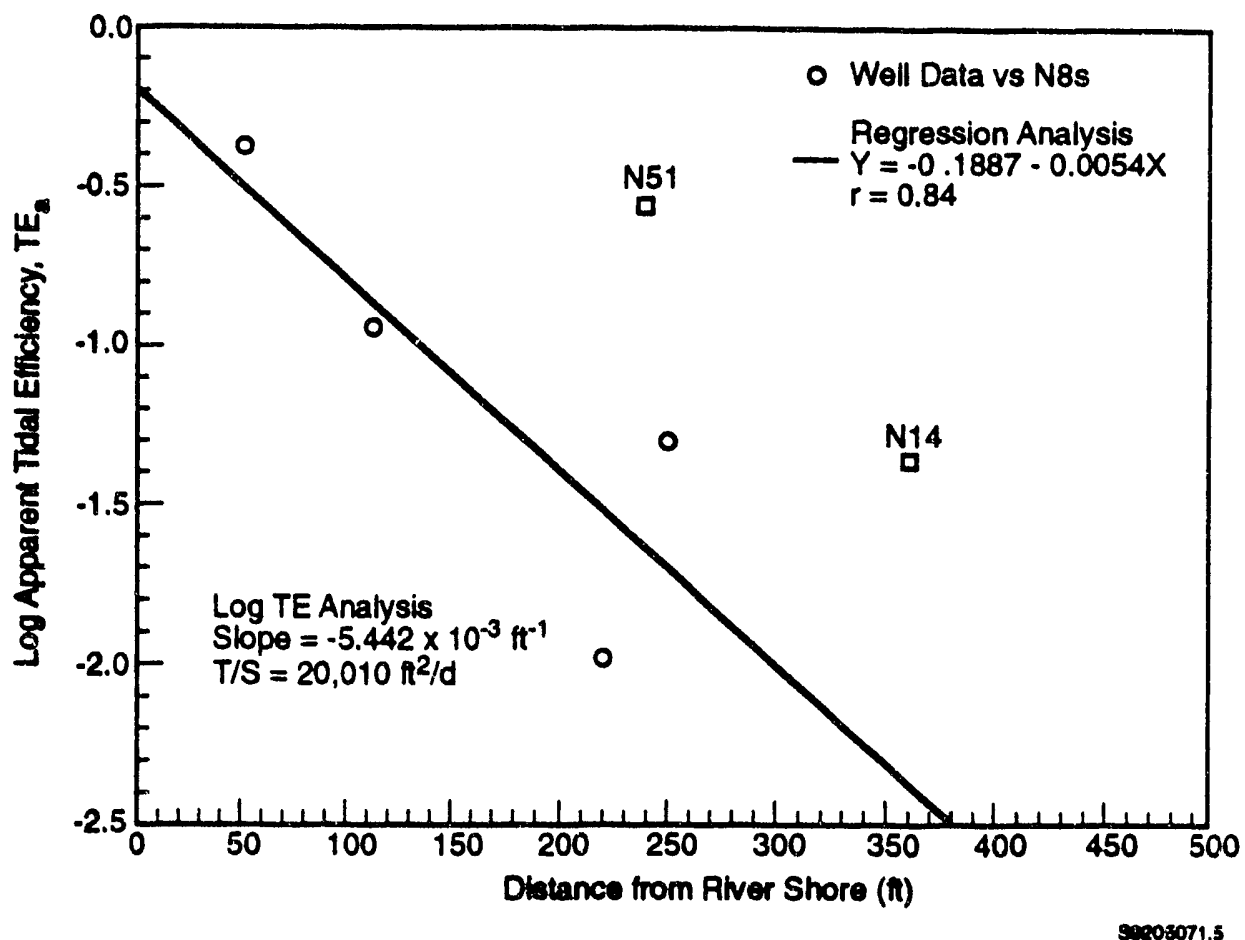

Figure 3.7. Composite Well Analysis Results for Apparent Tidal Efficiency (TE ${ }_{\mathrm{a}}$ ) Using Well N-8s as Point of Applied River Stress 
In summary based on composite well analysis, a best estimate range for the average hydraulic diffusivity for the unconfined aquifer in the southwest crosssectional area is $20,010 \mathrm{ft}^{2} / \mathrm{d}$ to $49,890 \mathrm{ft}^{2} / \mathrm{d}$. The range in average hydraulic diffusivity varies by a factor of two (i.e., for both composite analyses). The diffusivity for the unconfined aquifer in the vicinity of the northeast group of wells appears to be more than twice that calculated for the region encompassing the southwest area wells.

The Ferris sinusoidal method does not permit calculation of the individual components of hydraulic diffusivity (i.e., transmissivity and storativity). 'However, if the value for transmissivity of approximately $5,640 \mathrm{ft}^{2} / \mathrm{d}$ reported from the reanalysis of well $\mathrm{N}-32$ (see Section 2.0 ) is representative of the unconfined aquifer in this area, then a storativity range of between 0.11 and 0.28 is indicated. This storativity range estimate is within the range for specific yield commonly reported for the unconfined aquifer on the Hanford Site. [Note: storativity or specific yield for an unconfined aquifer is the yield of the aquifer per unit area and unit drop of the water table (Bear 1979)]. 


\subsection{Aquifer Parameter Estimation Using the Groundwater Flow Equation}

This section describes results from the analysis to determine aquifer diffusivity using the basic flow equation for groundwater. As with the Ferris Method (Section 3.0) the purpose of this analysis was to obtain average areal estimates of hydraulic diffusivity for the unconfined aquifer.

The Boussinesq equation is the basic continuity equation for groundwater flow in a phreatic aquifer with a horizontal impervious base. The equation is derived on p. 113 of Bear (1979).

$$
\frac{\partial}{\partial x}\left(h \frac{\partial h}{\partial x}\right)+\frac{N}{K}=\frac{S}{\bar{K}} \frac{\partial h}{\partial t}
$$

where $h=h(x, t)$ is the height of the water table

$N=N(x, t)$ is an external source/sink term

$\mathrm{S}=$ Specific yield of the aquifer

$\mathrm{K}=$ hydraulic conductivity of aquifer.

Equation 4 is nonlinear because of the product $\partial \mathrm{h} / \partial \mathrm{x}$. Two methods of linearization to facilitate a solution are described in Bear $(1979$, p. 115). The linearized version of Equation 4 is shown in Equation 5.

$$
\frac{\partial^{2} h}{\partial x^{2}}=\frac{S}{T} \frac{\partial h}{\partial t}
$$

Note: Diffusivity $=k h / S=T / S$.

Equation 5 is only valid when changes $\partial \mathrm{h} / \partial \mathrm{x}$ and $\partial \mathrm{h} / \partial \mathrm{t}$ are small relative to the total height $\mathrm{h}$. Equation 5 can then be solved using a one-dimensional, fully implicit finite-difference technique (Fletcher 1988). In finite-difference form Equation 5 becomes:

$$
-\frac{K \bar{h}}{S} \frac{\Delta t}{(\Delta x)^{2}} h_{i-1}^{j+1}+\left(1+2 \frac{K \bar{h}}{S} \frac{\Delta t}{(\Delta x)^{2}}\right) h_{i}^{j+1}-\frac{K \bar{h}}{S} \frac{\Delta t}{(\Delta x)^{2}} h_{i+1}^{j+1}=h_{i}^{j}
$$


where $h_{i}^{j}=$ water-table height at the $i$-th spatial node and the $j$-th time step

$\Delta \mathbf{x}=$ constant grid spacing

$\Delta \mathrm{t}=$ constant time step.

Equation 6 is a system of linear equations that can be solved for $h_{i}$ at new time $j+1$, given initial condition $h_{j}$ at time $j$ and boundary conditions $h_{1}$ and $h_{i \max }$ at time $j+1$. Because the system of equations forms a tridiagonal matrix, it can be efficiently solved using Thomas' algorithm (e.g., Anderson et al. 1984).

Measured river-level data was used with Equation 6 in an iterative technique to determine aquifer diffusivity by matching predicted changes in groundwater levels with observed changes. A computer program (Appendix B) was used to repeatedly solve Equation 6 and update estimates of diffusivity until a good fit between data and predictions was obtained. The fit was judged by comparing the average absolute change in measured and predicted groundwater elevations for the last week of the simulation. Diffusivity was adjusted until these values agreed to within the specified accuracy $(0.1 \%)$. The program converged rapidly (usually less than 10 iterations). The numerical solutions were calculated with grid spacing $\Delta x=50 \mathrm{ft}$, and time steps $\Delta \mathrm{t}=800$ or $1600 \mathrm{~s}$ using as input linear interpolations of river-level data recorded at 3600 -s or 7200 -s intervals ( 1 or $2 \mathrm{hr}$ ). The program was validated by comparison with the analytical solution of Pinder et al. (1969).

A sample result of the program is presented in Figure 4.1, which shows the predicted and measured groundwater levels for Well 199-N8s in October 1990. After an initial spin-up period, the predicted changes in groundwater elevation closely resemble the measured changes, both in amplitude and in timing. The constant offset of approximately $1 \mathrm{ft}$ is attributed to errors in the distant-boundary condition and, because the program examines changes in water levels rather than absolute magnitude, the offset has little effect on the diffusivity estimate.

Assumptions of the flow equation method are that 1) the aquifer is phreatic with an impervious base, 2) the river fully penetrates the aquifer and 3) no significant vertical groundwater flow components are present (Dupuit assumption). The first two assumptions are satisfied at the 100-N Area as discussed in Section 3.0. Assumption 3 is probably valid for situations where monitor wells are not located immediately adjacent to the river and/or completed in a thick aquifer. For this investigation, wells were located between $80 \mathrm{ft}$ to $440 \mathrm{ft}$ from the river and have shallow completion intervals suggesting that vertical groundwater flow components were not significant. 


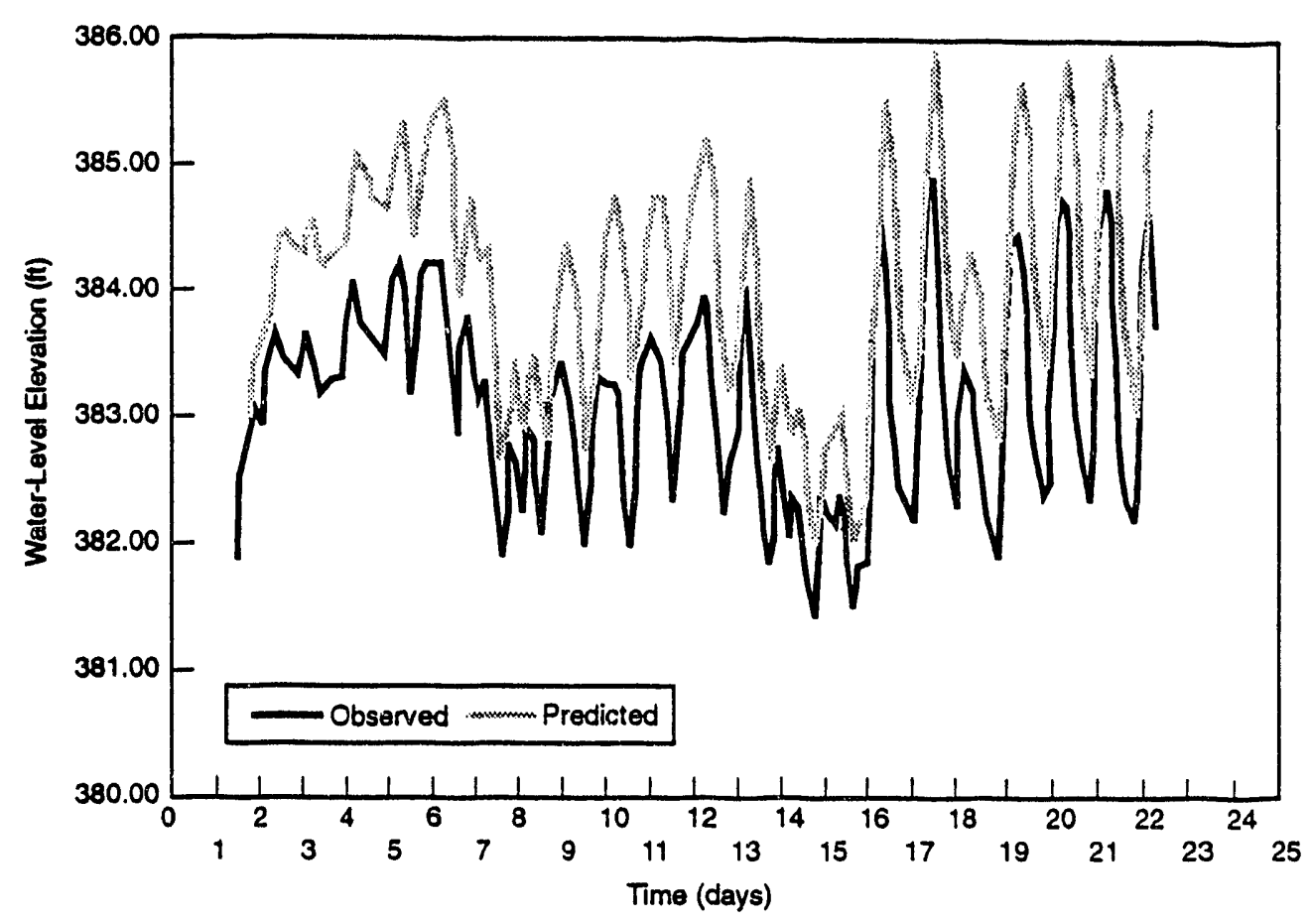

59205071.6

Figure 4.1. Comparison of Observed and the Predicted Water Levels for Well N-8s (October 1990)

The original data sets used in this analysis are from Gilmore et al. (1990) and the length of each set used as input to the computer program was for one month. In order to compare the diffusivity values of this method with the results from the Ferris method in Section 3.0, the same wells and periods of analysis (December 1989 and January 1990) were used. In addition, a period during the high river stage in June 1990 was used in the flow equation analysis. The June 1990 data could not be used in the Ferris method because the water-level fluctuations during this period were not cyclic and did not approximate a sinusoidal wave. The calculated diffusivity values, however, from both the high and low river stage showed no appreciable difference when the flow equation method was used (see Table 4.1).

The flow equation method provides the aquifer parameter, diffusivity; however, the numerical model requires the aquifer parameter, horizontal hydraulic conductivity. The hydraulic conductivity can be calculated from diffusivity by knowing the two variables: specific storage and aquifer thickness. These variables can be specified in the flow equation computer program input file for the calculation of hydraulic conductivity.

The calculation of hydraulic conductivity ( $k$ ) from a diffusivity value is very sensitive to the value assumed for the specific storage of the aquifer. For example, 
Table 4.1. N Area Flow Equation Method Diffusivity

\begin{tabular}{|c|c|c|}
\hline Well & Period & $\begin{array}{l}\text { Flow Equation } \\
\text { Method Diffusivity } \\
\left(\mathrm{ft}^{2} / \mathrm{d}\right)\end{array}$ \\
\hline N-8s & $\begin{array}{l}\text { Jan-90 } \\
\text { Oct-90 }\end{array}$ & $\begin{array}{l}32,000(64)^{(a)} \\
10,000(20)\end{array}$ \\
\hline $\mathrm{N}-8 \mathrm{p}$ & $\begin{array}{l}\text { Jan-90 } \\
\text { Jun-90 } \\
\text { Oct-90 }\end{array}$ & $\begin{array}{l}13,500(27) \\
26,500(53) \\
22,000(44)\end{array}$ \\
\hline $\mathrm{N}-20$ & $\begin{array}{l}\text { Jan-90 } \\
\text { Jun-90 } \\
\text { Oct-90 }\end{array}$ & $\begin{array}{l}10,000(20) \\
11,000(22) \\
11,000(22)\end{array}$ \\
\hline $\mathrm{N}-23$ & $\begin{array}{l}\text { Dec-89 } \\
\text { Jan-90 }\end{array}$ & $\begin{array}{l}21,500(43) \\
20,500(41)\end{array}$ \\
\hline $\mathrm{N}-25$ & $\begin{array}{l}\text { Dec-89 } \\
\text { Jan-90 }\end{array}$ & $\begin{array}{l}21,500(43) \\
12,500(25)\end{array}$ \\
\hline N-51 & $\begin{array}{l}\text { Dec-89 } \\
\text { Jan-90 } \\
\text { Jun-90 }\end{array}$ & $\begin{array}{l}100,500(201) \\
179,500(359) \\
207,500(415)\end{array}$ \\
\hline
\end{tabular}

(a) Hydraulic conductivity values $\left(\mathrm{ft}^{2} / \mathrm{d}\right)$ are in parenthesis and are based on $s=0.1$ and aquifer thickness at 50 feet.

a change in the specific storage from 0.1 to 0.2 changes the resultant $\mathrm{T}$ and $\mathrm{K}$ values by a factor of 2 . Specific storage is approximately equal to effective porosity and is defined as yield of the aquifer per unit height for a unit drop in water-table height (Bear 1979, p. 88). To directly measure specific storage, a sediment core sample can be tested for bulk density. However, the specific storage of the aquifer in the $100-\mathrm{N}$ Area is likely to vary both laterally and vertically due to the heterogenous nature of the sediments. Many samples would be needed to adequately define the average specific storage over the study area. In a compilation of hydrologic parameters of the Columbia Basin, Gephart et al. (1979) reported values of storage coefficients for the unconfined aquifer ranging from 0.01 to 0.1 . For this report, a conservative specific storage value of 0.1 was assumed. This is a conservative value because it results in a higher groundwater flux. 
The aquifer in the 100-N Area is approximately 35 to $60 \mathrm{ft}$ thick. The bottom of the aquifer is formed by a Mud unit within the Ringold Formation composed of $75 \%$ mud (undifferentiated silt and clay) at approximately $100 \mathrm{ft}$ below the land surface ( $350 \mathrm{ft}$ elevation) based on geologic logs of the now abandoned 699-86-60 well under the 1312 LERF facility and well N-5.

Another variable that is required for the flow equation method is distance from the river to the well. Distances were calculated from an aerial photograph of the 100-N Area. The length of the 1325 Crib was used for scale. The digitized locations of the wells and the nearest point to the river were measured and then rounded to the nearest $10 \mathrm{ft}$. The river shore varies daily and seasonally so the distance from the well to the river is an approximation.

The results of applying this analytical technique to the $100-\mathrm{N}$ data are shown in Table 4.1. The resultant $\mathrm{T}$ and $\mathrm{K}$ values for each of the wells are very consistent with this method. Alth , ugh the flow equation method is simplification of flow in the aquifer, the results provide a good approximation of the aquifer properties and compare favorably with the aquifer test reanalysis results (Section 2.0) and Ferris method (Section 3.0). 


\subsection{Discussion}

The values for diffusivity and hydraulic conductivity derived from each of the three methods presented in Sections 2.0 through 4.0 are summarized in Table 5.1. The actual values derived from both the Ferris method (Section 3.0) and the flow equation (Section 4.0) are for diffusivity, but have been converted to hydraulic conductivity for comparison purposes using the relationship for hydraulic diffusivity ( $\mathrm{Kb} / \mathrm{S}=$ hydraulic diffusivity) and assuming a specific storage of 0.1 and an aquifer thickness of $50 \mathrm{ft}$. Hydraulic conductivity values are presented in parenthesis.

Examination of the diffusivity values of the wells in Table 5.1 indicares that the wells can be divided into two groups based on location, with wells $\mathrm{N}-14$ and $\mathrm{N}-51$ located in the northeast forming one group and all other wells $(\mathrm{N}-8 \mathrm{~s}, \mathrm{~N}-8 \mathrm{p}$, $\mathrm{N}-20, \mathrm{~N}-23, \mathrm{~N}-23, \mathrm{~N}-25, \mathrm{~N}-32$ ) located in the southwest comprising another distinct group. For both the Ferris method and the flow equation method, wells located in the northeast of the $100-\mathrm{N}$ Area $(\mathrm{N}-14, \mathrm{~N}-51)$, display diffusivity values that are significantly higher than wells comprising the group located in the southwest of the 100-N Area. For the flow equation method, the diffusivity results are an order-ofmagnitude different between the two groups. This variation based on location appears to have a hydrologic basis and may be caused by lithologic changes in the aquifer's sediments to the northeast of the 1301-N LWDF (Gilmore et al. 1990).

In comparing results obtained for the three methods, it is evident that the Ferris method (based on time-lag analysis) and aquifer test reanalysis yield the highest values and the flow equation and Ferris method (based on apparent tidal efficiency analysis) the lowest values. These methods were used to estimate the upper and lower limits for a range of diffusivity values (hydraulic conductivity values in parenthesis). Because the southwest and northeast groupings of wells discussed above appear to comprise distinct groups, the two groups will be treated separately.

For the southwest grouping of wells the reanalysis of the aquifer pumping test forms the upper limit of this range at $112,800 \mathrm{ft}^{2} / \mathrm{d}(295 \mathrm{ft} / \mathrm{d})$. The lower bounds of this range, $18,000 \mathrm{ft}^{2} / \mathrm{d}(36 \mathrm{ft} / \mathrm{d})$, is the average of the wells analyzed using the flow equation method. The composite analysis results of all the wells using the Ferris technique falls in the middle, ranging between $20,010 \mathrm{ft}^{2} / \mathrm{d}$ (40 ft/d) based on the composite/well apparent tidal efficiency analysis, and $36,480 \mathrm{ft}^{2} / \mathrm{d}(73 \mathrm{ft} / \mathrm{d}$ ) - based on the composite/well time-lag analysis (Table 3.2). Although data from the two wells that form the northeast groupings of wells are limited, a range of diffusivity values can be estimated using the results of the two techniques. The average for the two wells using the Ferris technique forms the lower limit of $140,000 \mathrm{ft}^{2} / \mathrm{d}(280 \mathrm{ft} / \mathrm{d})$ and the upper limit of $162,500 \mathrm{ft}^{2} / \mathrm{d}$ $(325 \mathrm{ft} / \mathrm{d}$ ) is the average for well N-51 using the flow equation method. (Note: The unrealistic value obtained for well N-51 using the Ferris time-lag method was not included in the lower limit calculation). When these values are converted to 
hydraulic conductivity (with $s=0.1$ and aquifer thickness $=50 \mathrm{ft}$ ), these results compare favorably with the reported ranges of hydraulic conductivities within the Columbia Plateau for the Ringold Formation of $10^{1}$ to $10^{2} \mathrm{ft} / \mathrm{d}$ (Gephart et al. 1979).

Table 5.1. N Area Diffusivity, Flow Equation and Ferris Method

\begin{tabular}{|c|c|c|c|c|}
\hline Well & Period & $\begin{array}{c}\text { Flow Equation } \\
\text { Method } \\
\text { Diffusivity } \\
\left(\mathrm{ft}^{2} / \mathrm{d}\right) \\
\end{array}$ & $\begin{array}{l}\text { Ferris Method } \\
\text { Diffusivity } \\
\left(\mathrm{ft}^{2} / \mathrm{d}\right)\end{array}$ & 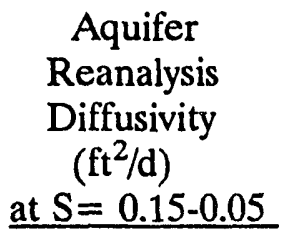 \\
\hline$N-8 s$ & $\begin{array}{l}\text { Jan-90 } \\
\text { Oct-90 }\end{array}$ & $\begin{array}{l}32,000(64) \\
10,000(20)\end{array}$ & $11,500(23)^{(a)}$ & \\
\hline$N-8 p$ & $\begin{array}{l}\text { Jan-90 } \\
\text { Jun-90 } \\
\text { Oct-90 }\end{array}$ & $\begin{array}{l}13,500(27) \\
26,500(53) \\
22,000(44)\end{array}$ & $7,000(14)^{(a)}$ & \\
\hline N-3 & Oct-90 & & $8,890^{(b)}$ & \\
\hline $\mathrm{N}-14$ & Dec-89 & & $131,000(262)^{(c)}$ & \\
\hline N-20 & $\begin{array}{l}\text { Jan-90 } \\
\text { Jun-90 } \\
\text { Oct-90 }\end{array}$ & $\begin{array}{l}10,000(20) \\
11,000(22) \\
11,000(22)\end{array}$ & $10,000(20)^{(b)}$ & \\
\hline $\mathrm{N}-23$ & $\begin{array}{l}\text { Dec-89 } \\
\text { Jan-90 }\end{array}$ & $\begin{array}{l}21,500(43) \\
20,500(41)\end{array}$ & $27,000(54)^{(b)}$ & \\
\hline N-25 & $\begin{array}{l}\text { Dec-89 } \\
\text { Jan-90 }\end{array}$ & $\begin{array}{l}21,500(43) \\
12,500(25)\end{array}$ & $12,500(25)^{(b)}$ & \\
\hline N-32 & & & & $\begin{array}{c}37,600-112,800 \\
(295)\end{array}$ \\
\hline N-51 & $\begin{array}{l}\text { Dec-89 } \\
\text { Jan-90 } \\
\text { Jun-90 } \\
\text { Oct-90 }\end{array}$ & $\begin{array}{l}100,500(201) \\
179,500(359) \\
207,500(415)\end{array}$ & $148,000(296)^{(b)}$ & \\
\hline
\end{tabular}

(a) Based only on apparent tidal efficiency using distance to river (Table 3.1).

(b) Based on only apparent tidal efficiency analysis value (Table 3.2).

(c) Average of both apparent tidal efficiency analysis and time-lag analyses (Table 3.2).

Note: Hydraulic conductivity values in pa! snthesis $\left(\mathrm{ft}^{2} / \mathrm{d}\right)$. 
Results of this study indicate that despite the variability exhibited for the three methods, the range for hydraulic conductivity has been narrowed considerably in comparison to the range initially used for this region based on pumping test results $(104 \mathrm{ft} / \mathrm{d}$ to $8,400 \mathrm{ft} / \mathrm{d}$ ). (Note: the range of values used in Connelly et al. (1991) representing aquifer test values from wells N-27, N-32, N-34 was from 129 to $577 \mathrm{ft} / \mathrm{d})$.

This study narrowed the range of aquifer parameter values for the $100-\mathrm{N}$ Area and has identified two distinct areas of different diffusivity values. It was also determined that analytical techniques for determining aquifer properties based on a comparison of well and river stage water-level fluctuations compare favorably with more traditional aquifer pumping tests and provide valid results in the $100-\mathrm{N}$ Area of the Hanford Site. 


\subsection{References}

Anderson, D. A., J. C. Tannehill, and R. H. Pletcher. 1984. Computational Fluid Mechanics and Heat Transfer. Hemisphere Publishing Corporation, New York. 409 p.

Bear, J. 1979. Hydraulics of Groundwater. McGraw-Hill Publishing Co., New York. $569 \mathrm{p}$.

Bourdet, D., and A. Alagoa. September 1984. "New Method Enhances Well Test Interpretation." World Oil, pp. 37-44.

Carr, P. A., and G. S. Van Der Kamp. 1969. "Determining Aquifer Characteristics By the Tidal Method." Water Resources Research 5:5(1023-1031).

Carslaw, H., and J. Jaeger. 1959. Conduction of Heat in Solids. The Clarendon Press, Oxford.

Clark, W. E. - 1967. "Computing the Barometric Efficiency of a Well." American Society of Civil Engineering. Journal of the Hydraulics Division 4:93-98.

Clark, D. G., and T.D.V. Golg-Racht. November 1985. "Pressure Derivative Approach to Transient Test Analysis: A High Permeability North Sea Reservoir Example." Journal of Petrolium Technology pp. 2023-2038.

Connelly, M. P., J. D. Davis, and P. D. Rittman. 1991. Numerical Simulacion of Strontium-90 Transport from the 100-N Area Liquid Waste Disposal Facilities. WHC-SD-ER-TA-001 Rev. 0, Westinghouse Hanford Company, Richland, Washington.

Cooper, H. H. Jr., and C. E. Jacob. 1946. "A Generalized Graphical Method for Evaiuating Formation Constant and Summarizing Well-Field History." American Geophysics Union Transactions 27(4):526-534.

Cooper, H. H., and M. I. Rorabaugh. 1963. Groundwater Movements and Bank Storage Due to Flood Stages in Surface Rivers. U.S. Geological Survey, Water Supply Paper 1536-J, pp. 343-366.

DOE. 1988. Consultation Draft: Site Characterization Plan, Reference Repository Location. Hanford Site, Washington. DOE/PW-0164, U.S. Department of Energy, Washington D.C.

Earlougher, R. C., Jr. 1977. Advances in Well Test Analysis. Henry L. Doherty Series Monograph Volume 5, Society of Petroleum Engineers, Dallas, Texas. 
Erskine, A. D. 1991. "The Effect of Tidal Fluctuation on a Coastal Aquifer in the UK." Ground Water 29(4):556-562.

Ferris, J. G. 1952. Cyclic Fluctuations of Water Level As a Basis for Determining Aquifer Transmissibility. U.S. Geological Survey, Ground-Water Hydraulics Section, Contribution No. 1,17 p.

Ferris, J. G. 1963. Cyclic Fluctuations of Water Level As a Basis for Determining Aquifer Transmissibility. U.S. Geological Survey, Water Supply Paper 1536-I, pp. 305-318.

Fletcher, C.A.J. 1988. Computational Techniques for Fluid Dynamics 1 Fundamental and General Techniques. Springer-Verlag, New York. 599 p.

Gephart, R. E., R. C. Arnett, R. G. Baca, L. S. Leonhart, and F. A. Spane, Jr. 1979. Hydrologic Studies within the Columbia Plateau, Washington: An Integration of Current Knowledge. RHO-BWI-ST-5, Rockwell Hanford Operations, Richland, Washington.

Gilmore, T. J, J. V. Borghese, J. P. McDonald, and D. R. Newcomer. 1990. Evaluations of the Effects of the Columbia Piver on the Unconfined Aquifer Beneath the 1301-N Liquid Waste Disposal Facility. PNL-7341, Pacific Northwest Laboratory, Richland, Washington.

Gregg, D. O. 1966. "An Analysis of Ground-Water Fluctuations Caused By Ocean Tides in Glynn County Georgia." Ground Water 4(3):24-32.

Jacob, C. E. 1946. "Radial Flow in a Leaky Artisan Aquifer." American Geophysics Union Transactions 27(2):198-205.

Jacob, C. E. 1963. "Determining the Permeability of Water-Table Aquifers," in Methods of Determining Permeability, Transmissibility, and Drawdown. U.S. Geological Survey, Water-Supply Paper 1536-I.

Kipp, K. L., and R. D. Mudd. 1973. Collection and Analysis of Pump Test Data for Transmissivity Values. BNWL-1709, Pacific Northwest Laboratory, Richland, Washington.

Newcomb, R. C., J. R. Strand, and F. J. Frank. 1972. Geology and Ground-Water Characteristics of the Hanford Reservation of the U.S. Atomic Commission, Washington. U.S. Geological Survey, Professional Paper 717.

PNL. 1988. Ground-Water Monitoring Compliance Projects for Hanford Site Facilities: Progress Report for the Period April 1 to June 30, 1988. PNL-6675, Pacific Northwest Laboratory, Richland, Washington. 
Pinder, G. P., J. D. Bredehoeft, and H. H. Cooper, Jr. 1969. "Determination of Aquifer Diffusivity from Aquifer Response to Fluctuations in River Stage." Water Resources Research 3(4):850-855.

Reynolds, R. J. 1987. "Diffusivity of a Glacial-Outwash Aquifer by the Floodwave-Response Technique." Ground Water 25(3):290-299.

Rowe, P. P. 1960. "An Equation for Estimating Transmissibilityand Coefficient of Storage from River Level Fluctuations." Journal of Geophysical Research 65(10):3419-3424.

Spane, F. A., Jr. 1992. Hydraulic Test Results for Savage Island Wells 699-3222B, 699-42-E9A, and 699-42-E9B. Pacific Northwest Laboratory, PNL-8173, Richland, Washington.

Theis, C. V. 1935. "Relationship Between the Lowering of the Piezometric Surface and the Rate and Duration of Discharge of a Well Using Ground-Water Storage." American Geophysics Union Transactions pt. 2, pp. 519-524.

Walton, W. C. 1987. Groundwater Pumping Tests: Design \& Analysis. Lewis Publishers, Inc., Chelsea, Michigan.

Weeks, E. P. 1979. "Aquifer Tests - The State of the Art in Hydrology." Proceedings of the Invitational Well-Testing Symposium, October 19-21, 1977, Berkeley, California. LBL-7027, Lawrence Berkeley Laboratory, Berkeley, California. 


\section{Appendix A}

\section{Aquifer Test of Well 199-N-32}




\section{Appendix A}

\section{Well 199-N-32}

A 24-hr constant-rate pumping test at well $199-\mathrm{N}-32$ was initiated on March 26, 1984. Discharge rates varied during the course of the test, and averaged approximately $100 \mathrm{gpm}$. Observation well 199-N-33, located $515 \mathrm{ft}$ from well 199-N.32, was monitored during the test, but no drawdown was observed.

Available test data records indicate (i.e., as suggested by recoverying water levels) that the well 199-N-32, was still developing during the later stages of the pumping test. Because of the discharge rate variability and presence of well development during the discharge test, drawdown test data were not reanalyzed. Recovery test data for well 199-N-32 following termination of pumping, however, were evaluated diagnostically using a log-log pressure change and pressure change derivative plot to identify characteristic flow regimes and conditions exhibited within the recovery data. A quantitative semi-log analysis of the radial flow portion of the recovery water-level data record, as indicated from the log-log pressure derivative plot, was then applied. A detailed description of the use of log-log diagnostic and semi-log straight-line analysis methods is presented in Spane (1992).

Figure A.1 shows that $\log -\log$ recovery data and recovery data derivative plot following the constant-rate pumping test. The recovery derivative was calculated using the Agarwal time equivalent function following the procedure outlined in Bourdet and Alagoa (1984). Using the Agarwal time equivalent function accounts for the length of the drawdown time period, and allows recovery plots to be analyzed with drawdown type curves. The time equivalent function, $\Delta t_{e}$, is defined by Agarwal (1980) as:

$$
\Delta \mathrm{t}_{\mathrm{e}}=\left(\mathrm{t} \times \mathrm{t}^{\prime}\right) /\left(\mathrm{t}+\mathrm{t}^{\prime}\right)
$$

where, $t=$ duration of the pumping test; $(T)$

$$
\mathrm{t}^{\prime}=\text { time since pumping terminated; }(\mathrm{T})
$$

As shown in the Figure A.1, diagnostic analysis of the log-log recovery data and data derivative plot indicates the following effects and conditions during the recovery period:

- wellbore storage effects dominant up to a $\Delta \mathrm{t}_{\mathrm{e}} \approx 0.15 \mathrm{~min}$ 
- delayed-yield conditions significant during the time period $\Delta \mathrm{t}_{\mathrm{e}} \approx 0.15 \mathrm{~min}$ to $6 \mathrm{~min}$

- radial flow conditions established between the time period $\Delta \mathrm{t}_{\mathrm{e}} \approx 6 \mathrm{~min}$ to $200 \mathrm{~min}$, and

- presence of a recharge boundary after a $\Delta t_{e} \approx 200 \mathrm{~min}$.

The presence of a recharge boundary in the later stages of recovery are attributed. either to wastewater discharges occurring at the $1301-\mathrm{N}$ crib facility, surface discharge of groundwater withdrawn during the constant-rate pumping test, or the recharge boundary condition imposed by the Columbia River.

Figure A.2 shows the semi-log, straight-line analysis of recovery data utilizing the Theis (1935) recovery method. Only recovery data that exhibit radial flow conditions (i.e., $\Delta t_{e}=6$ to $200 \mathrm{~min} ;\left\{t+t^{\prime}\right\} / t^{\prime}$ ) were analyzed. As indicated in the figure, an estimate of $5,640 \mathrm{ft}^{2} / \mathrm{d}$ was obtained form the straight-line analysis.

Recovery data shown in Figures A.1 and A.2 were corrected for unconfined aquifer de-watering using the procedure presented in Jacob (1963). Partial penetration effects were evaluated with applicable software presented in Walton (1987). The analysis indicated that partial-penetration effects were relatively constant during the radial flow period of the test data and, therefore, of no significant consequence to the straight-line analysis of test data exhibiting radial flow conditions.

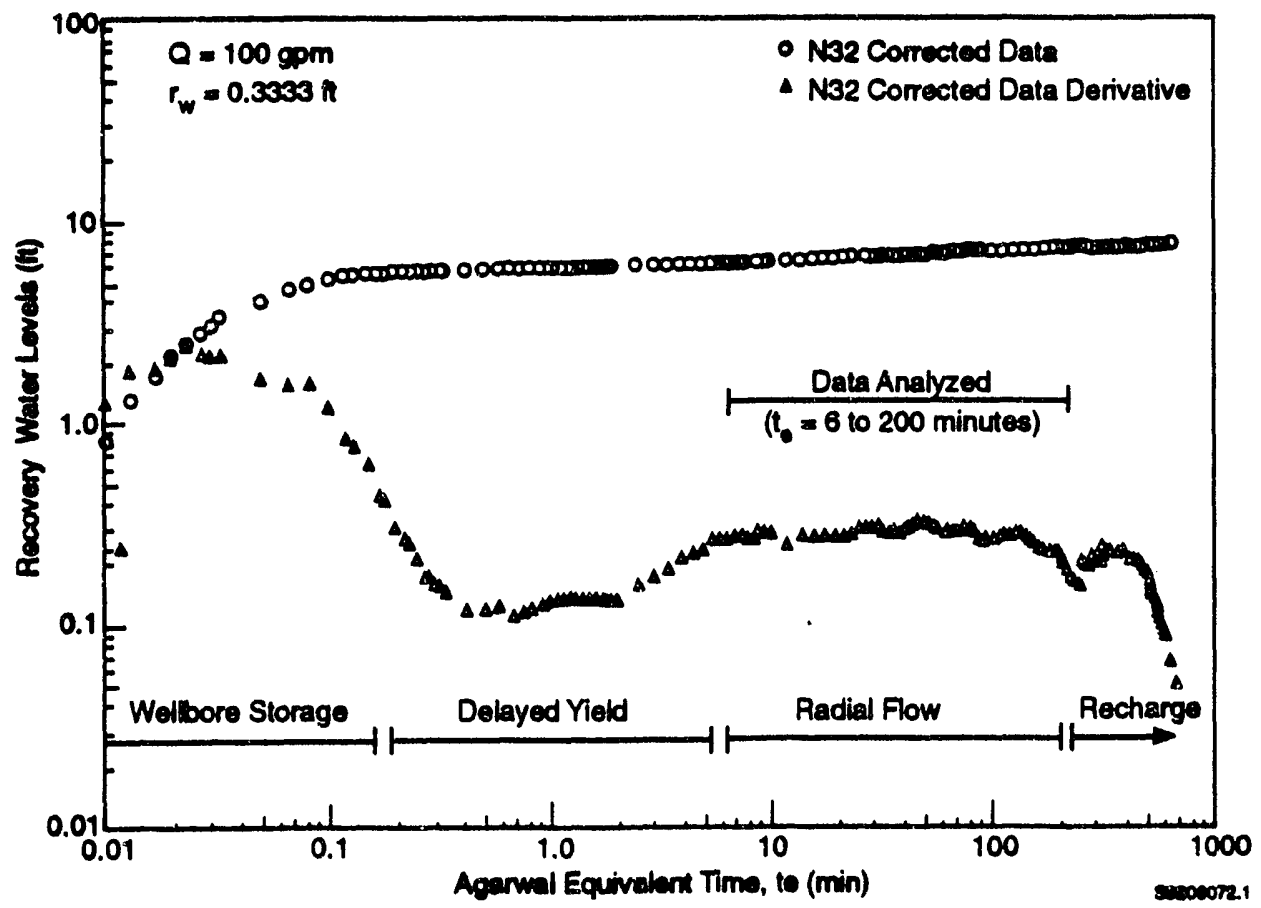

Figure A.1. Log-Log Plot of Water-Level Recovery Data and Pressure Derivative of Recovery Data 


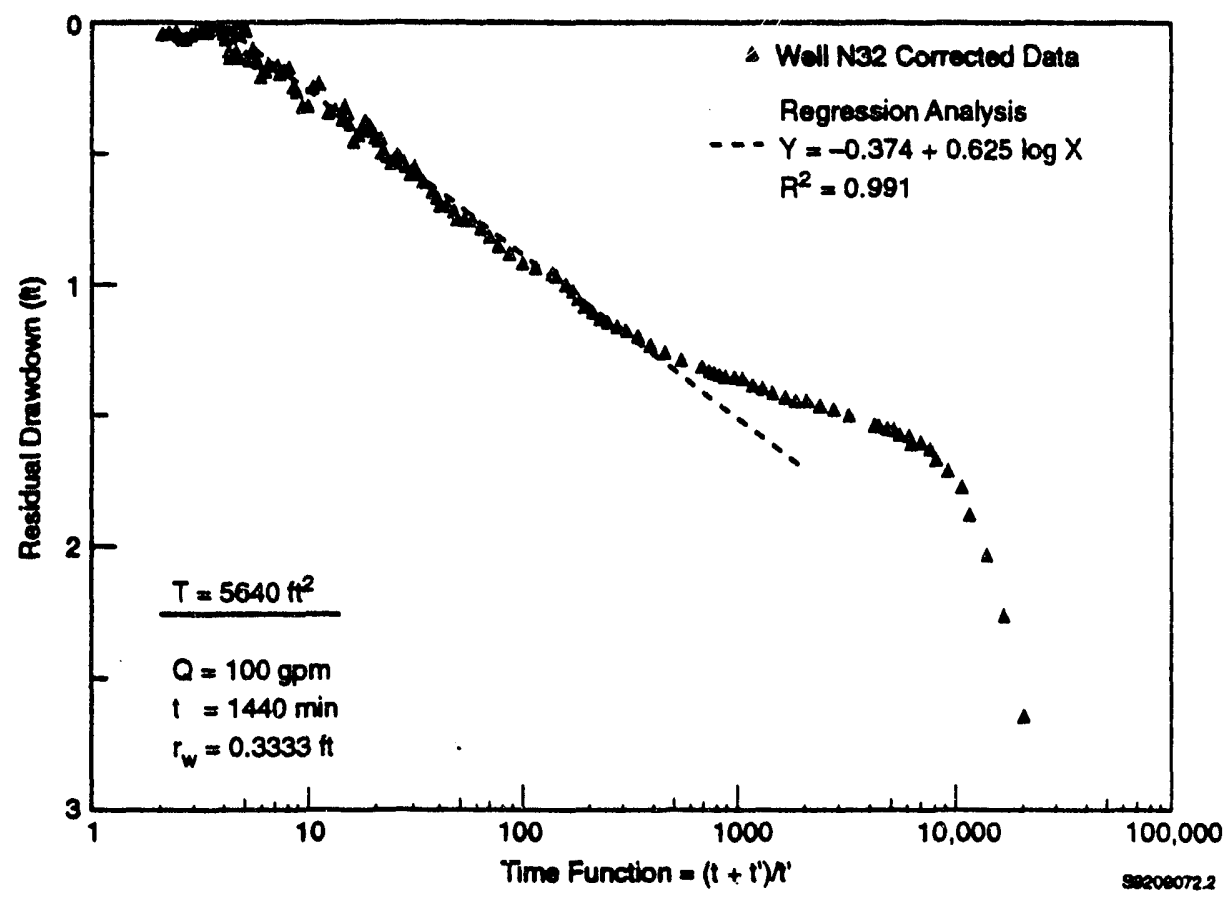

Figure A.2. Semi-Log Plot of the Water-Level Recovery Data 


\section{Appendix B}

\section{Computer Code for Aquifer Parameter Estimation}




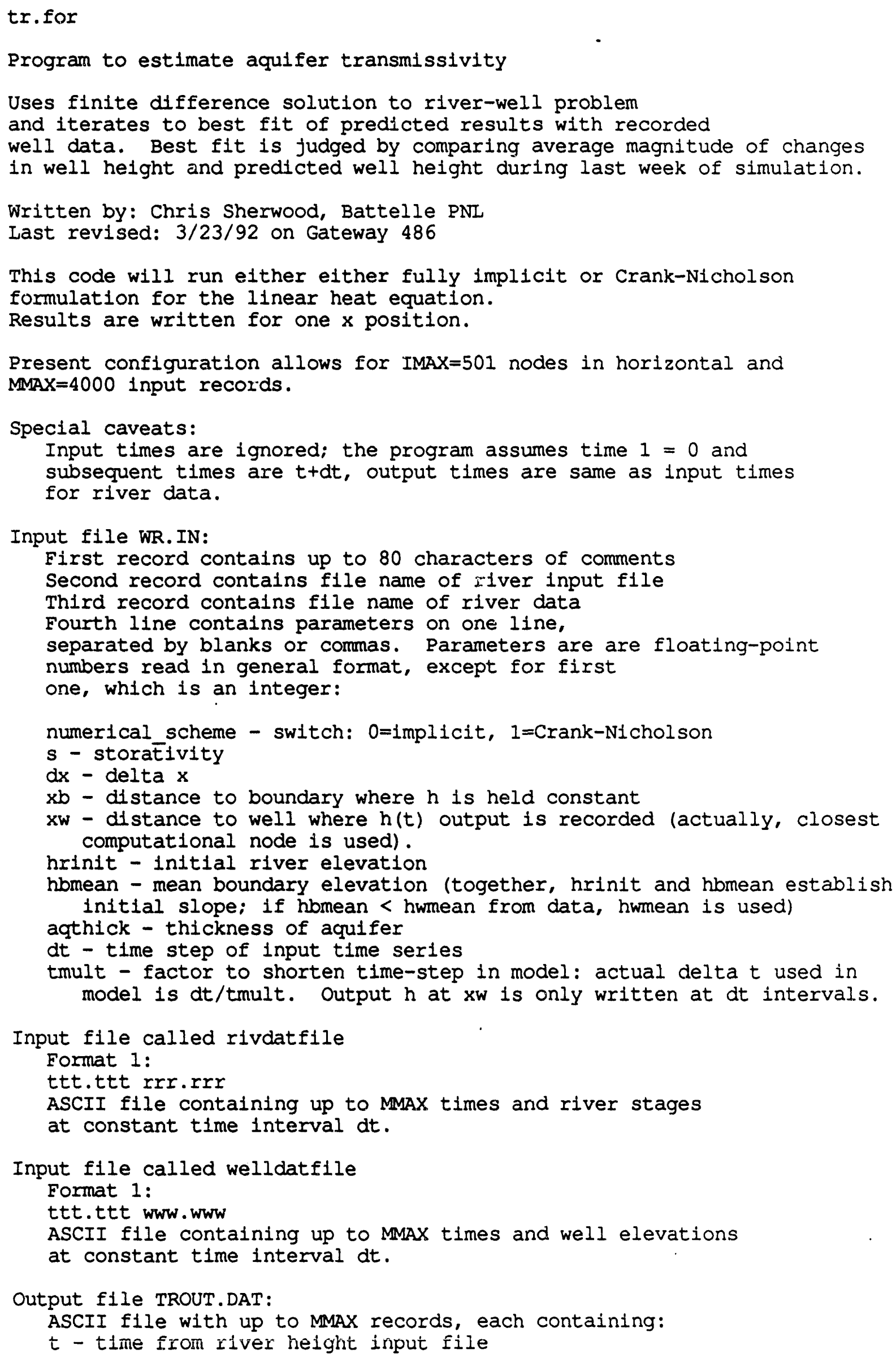




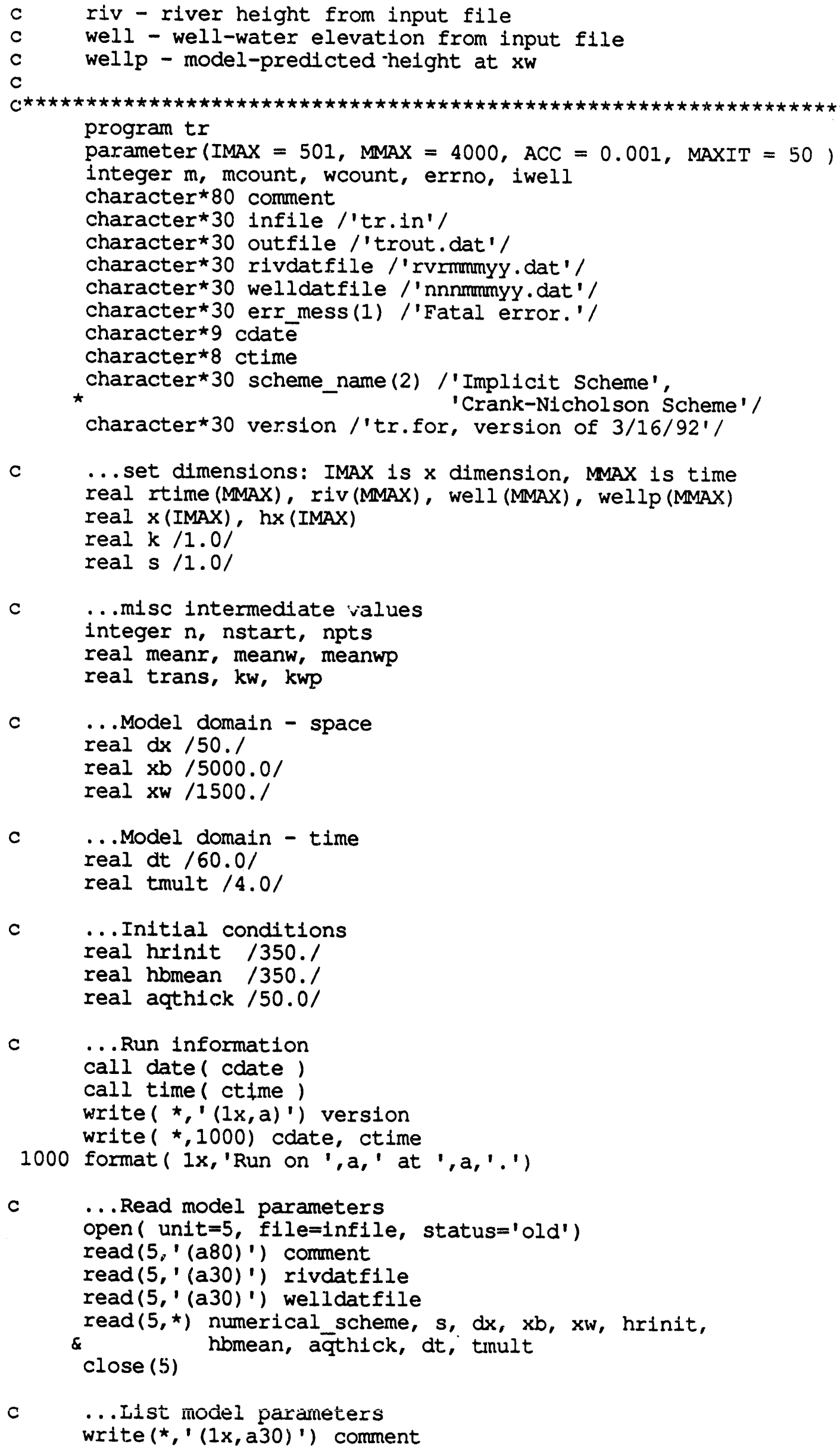

B. 2 
write $(*, 1005)$ rivdatfile, welldatfile

1005 format (1x,' River data file: ', a30,/,

\& $1 \mathrm{x}$, 'Well data file : ',a30)

write (*,' (1x,a)') scheme_name (numerical_scheme+1)

write $(*, 1010) s, d x, d t$

1010 format $(1 \mathrm{x}$, 's $=1, \mathrm{~F} 9.4,1$,

\& $\left.\quad 1 \mathrm{x}, 1 \mathrm{dx}=1, \mathrm{F9} .4,{ }^{\prime} \quad d t=1, \mathrm{F9} .4\right)$

write $(*, 1020)$ hrinit, hbmean, aqthick

1020 format $(1 \mathrm{x}$, ' hrinit $=1$, F7.2,' hbmean $=1, F 7.2,1$,

\&

$1 \mathrm{x}$, 'aqthick $=1, \mathrm{~F} 7.2$ )

c $\quad$...Read in time-history of river data

open $(5, f 1 l e=r i v d a t f 1 l e$, status $=$ ' old')

write $(*, 2000)$ rivdatfile

2000 format (1x, 'Reading river input flle: ',a)

mcount $=0$

do $200 \mathrm{~m}=1$, MAX

$\operatorname{read}(5, \star$, end $=209) \operatorname{rtime}(\mathrm{m}), \operatorname{riv}(\mathrm{m})$

200 continue

209 close (5)

if ( mcount .eq. 0 ) then

write $(*, \star)$ 'Error reading input file.' stop

else if ( mcount .eq. MMAX) then

write $(*, *)$ '... done. Read ',mcount,' points.'

write $(\star, *), 1 \star \star \star$ WARNING $\star \star \star * !$

else

write $(*, \star)$ 'Array full; may not have read all points.'

endtf

c $\quad$...Read in time-history of river data

open (5, file=welldatfile, status=' old')

write $(*, 2001)$ welldatfile

2001 format(1x,' Reading woll input file: ',a)

wcount $=0$

do $201 \mathrm{~m}=1$, mcount

$\operatorname{read}(5, *$, end $=219)$ wtime, well $(m)$

201

wcount $=$ wcount +1

close (5)

if ( wcount .eq. 0 ) then

write $(*, *)$ 'Error reading input file.'

stop

c

c bug fix -- changed .le. to .1t. -- SK wurstner $3 / 23 / 92$

else if ( wcount. it. mcount) then

write $(*, \star)$ '...done. Read ',wcount,' points.'

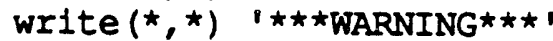

write $(*, \star)$ 'Well data shorter than river data.'

c $\quad$...process fewer points

mcount $=$ wcount

else endif

write $(*, *)$ '...done. Read ',m,' points.'

c ...calculate means of river and well data

call mv ( rlv, mcount, hrmean, rsdev, 0 )

call mv ( well, mcount, hwmean: wsdev, 0)

if (hbmean .1t. hwmean) then

hbmean $=$ hwmean

write $(\star, \star) 1 \star \star \star$ Specified hbmean $<$ hwmean $\star \star \star \prime$ 


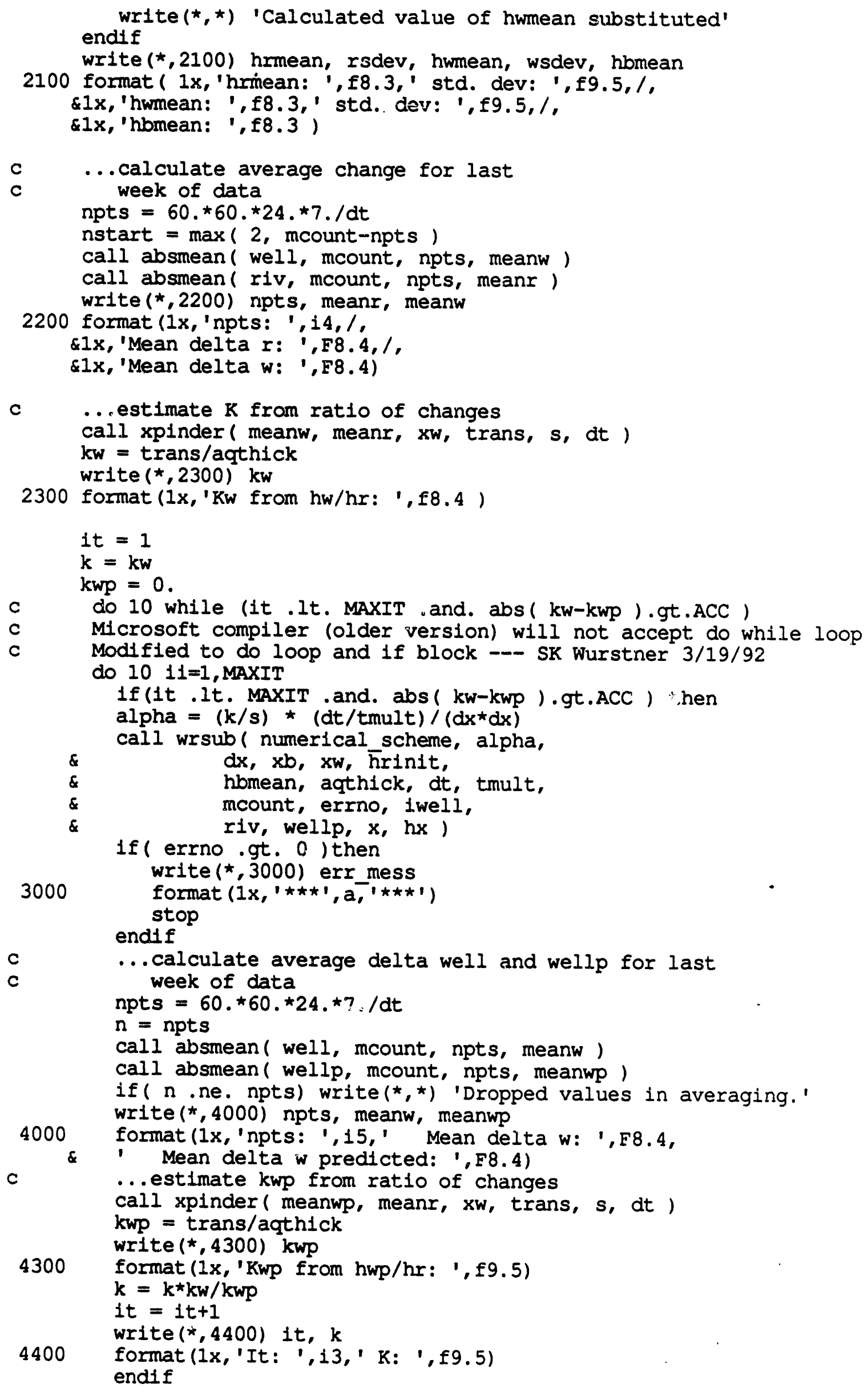

B.4 
10 continue

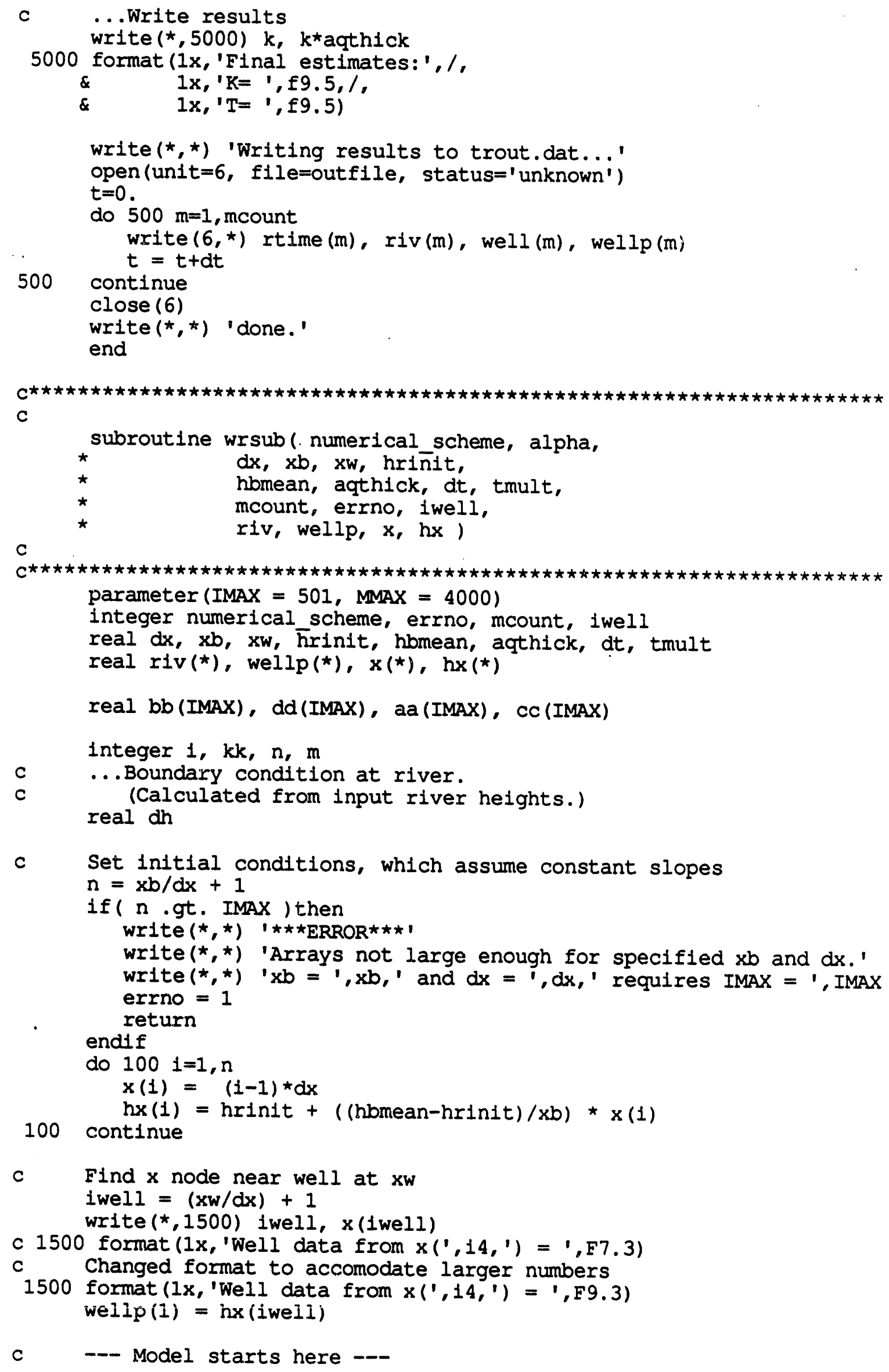




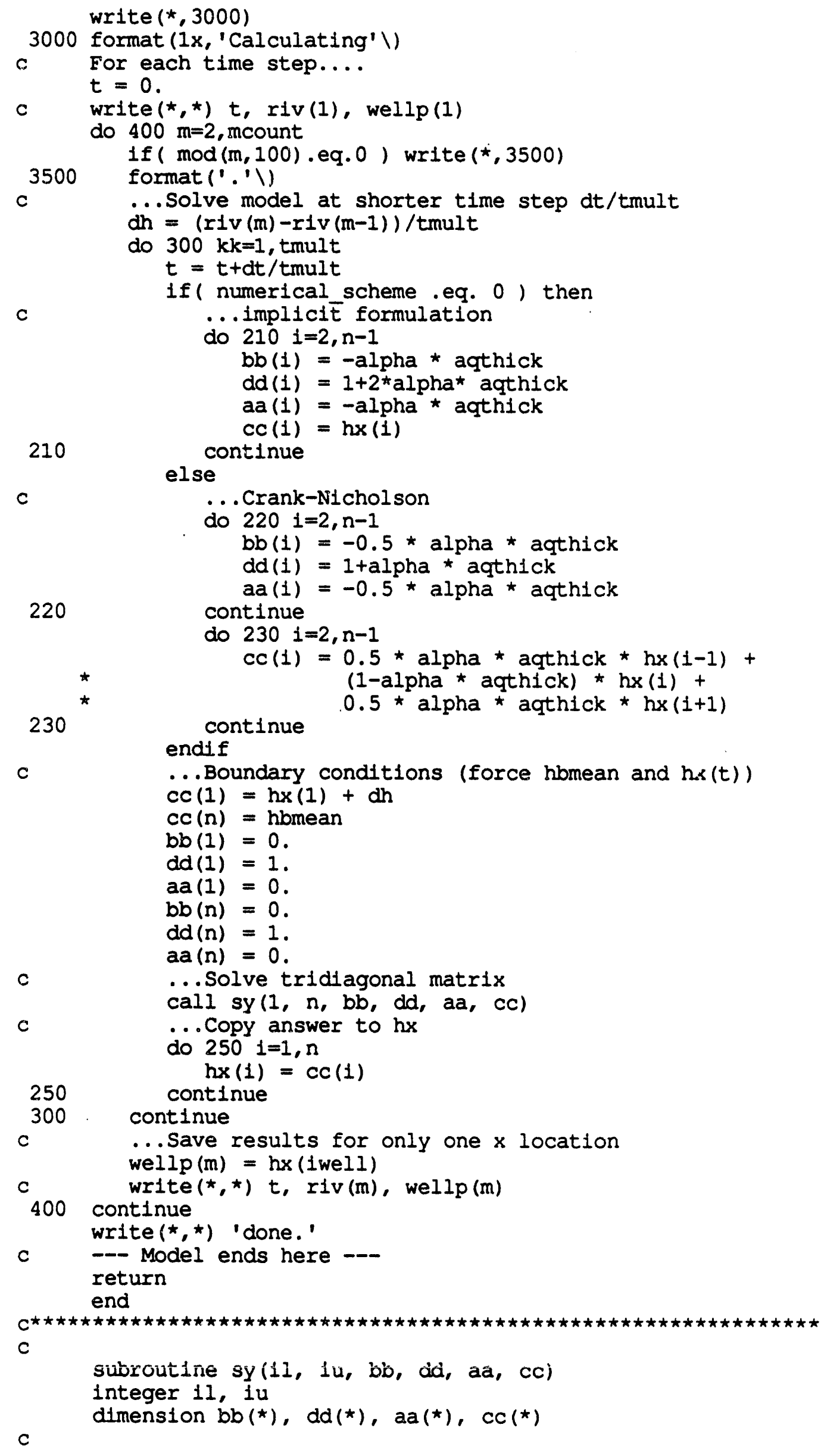




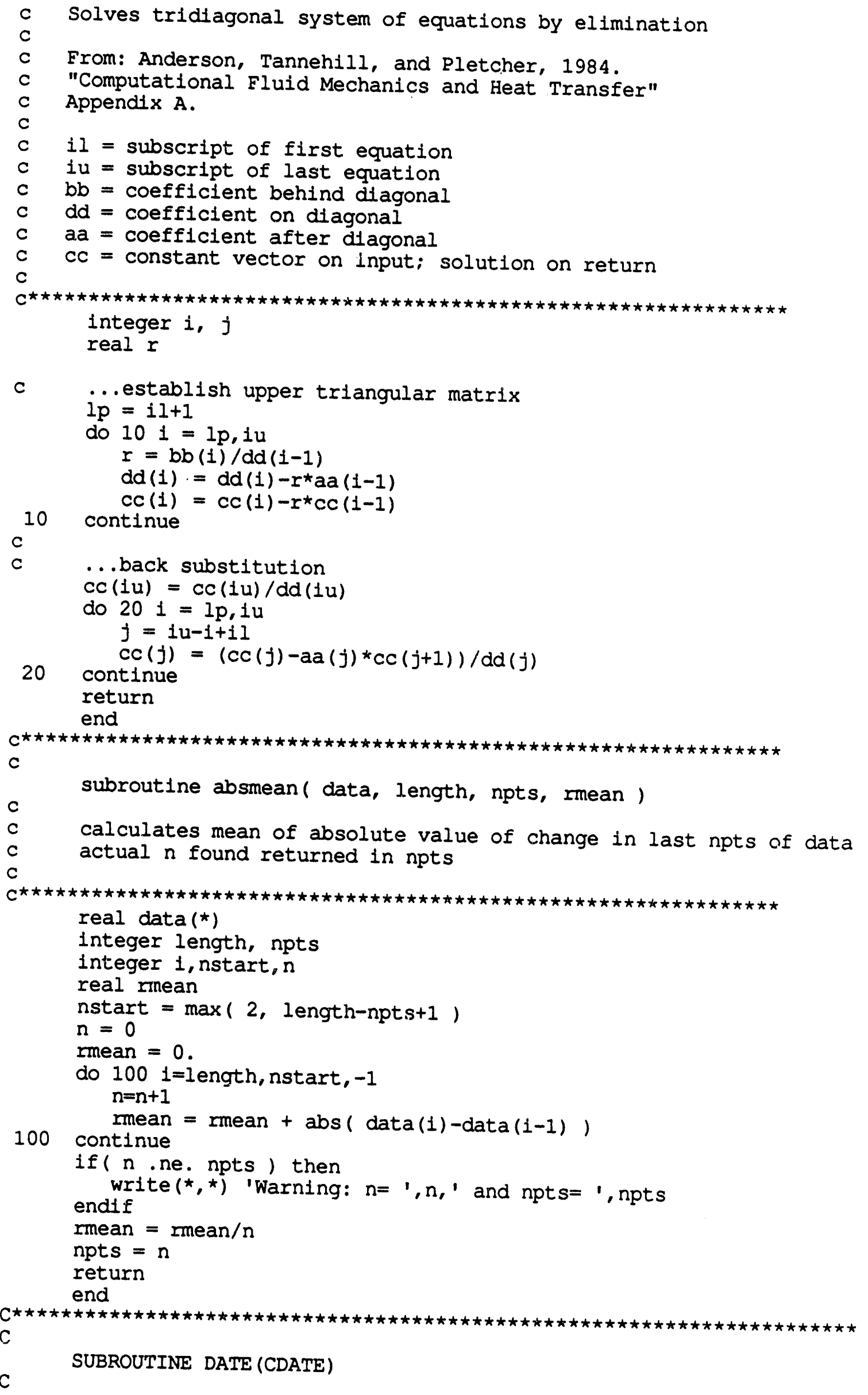




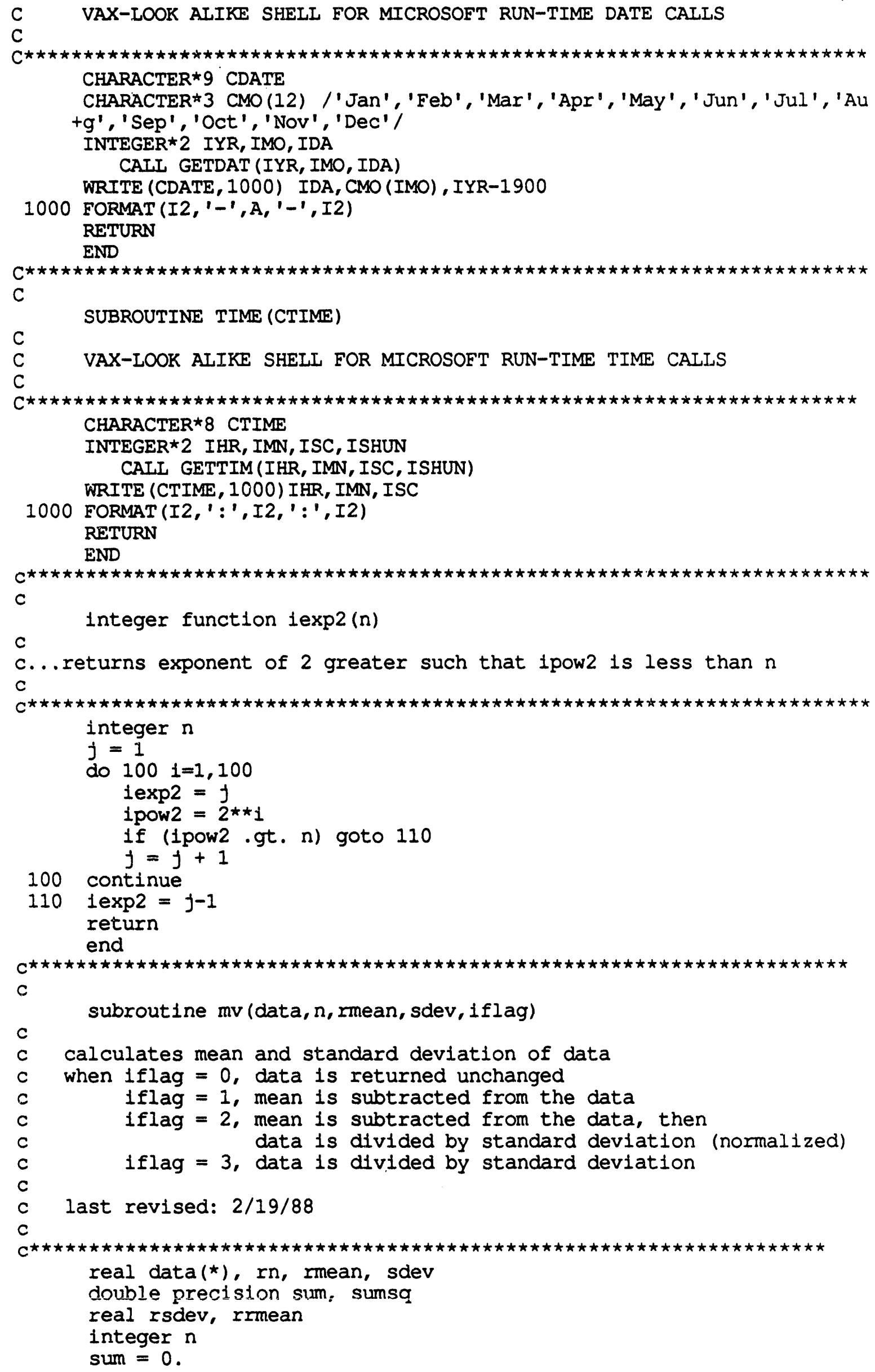

B.8 


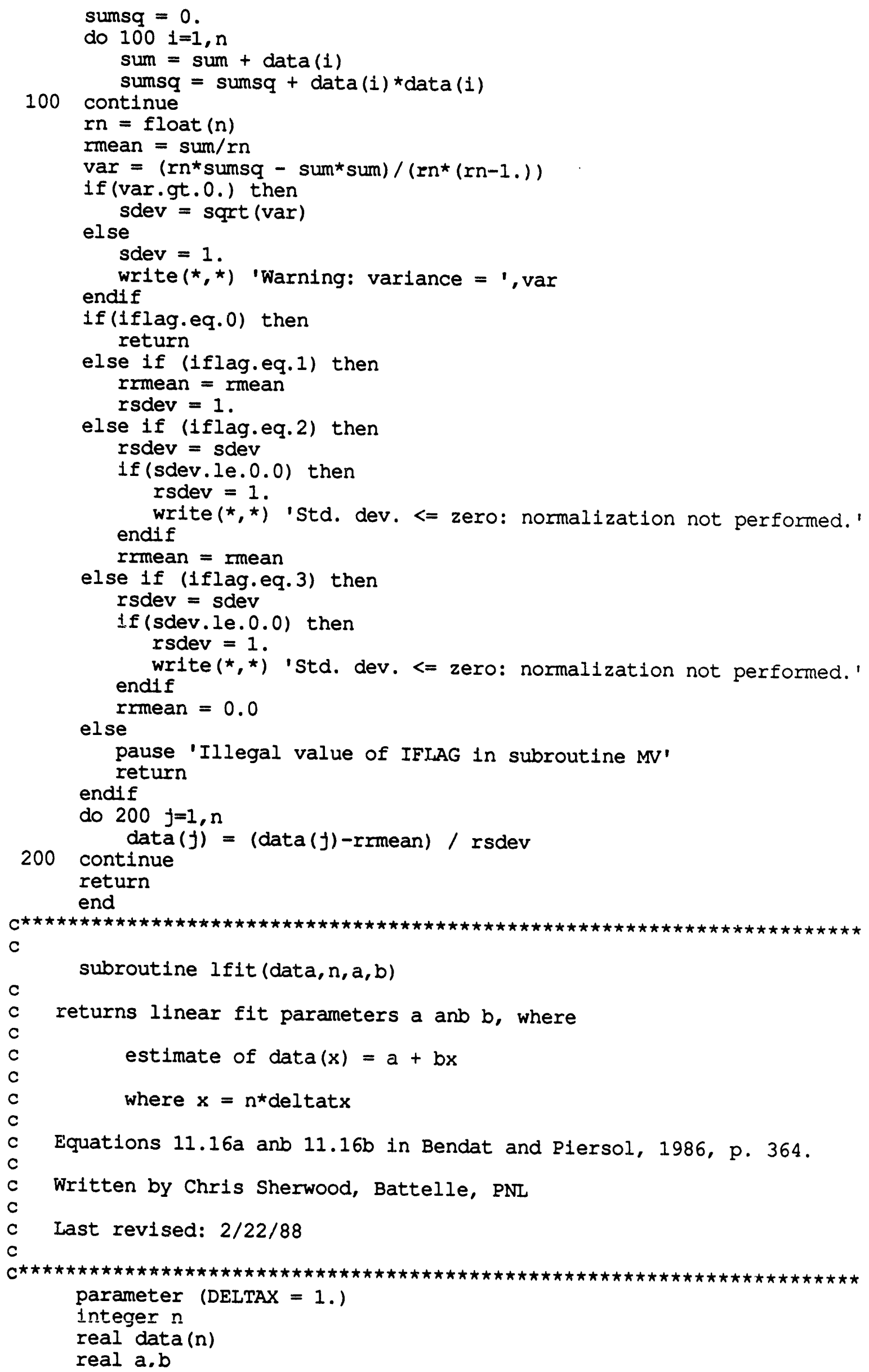




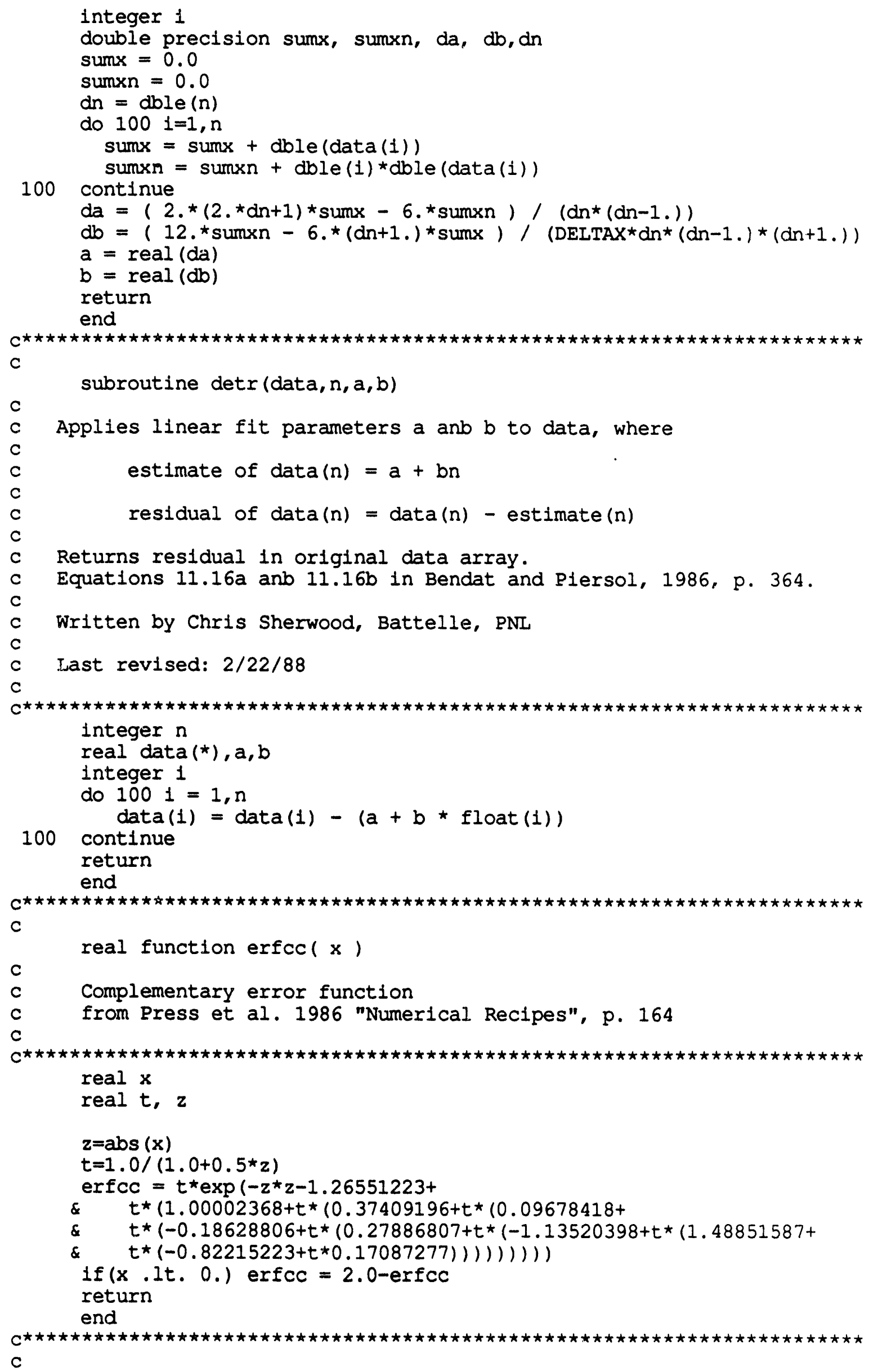


real function xerfcc(erfcx)

C

c Calculates $x$ given erfc $(x)$ by Newton's method

c Returns when accuracy XACC is reached or maximum

c number of iterations MAXIT is reached.

c

Based on RTNEWT in Press et. al. 1986, p. 254

Written by: Chris Sherwood, Battelle MSL

parameter $(\mathrm{XACC}=0.0001, \operatorname{MAXIT}=100)$

real erfcx

real $d x, f, d f$

real erfcc

$d x=1$

xerfcc $=.5$

do $101=1$, MAXIT

$f=\operatorname{erfcc}($ xerfcc $)-\operatorname{erfcx}$

$\&$

$d f=(\operatorname{erfcc}(x \operatorname{xerfcc}+5 \star X A C C)-\operatorname{erfcc}(x \operatorname{erfcc}-5 \star X A C C))$

$$
/(10 * X A C C)
$$

$\mathrm{dx}=\mathrm{f} / \mathrm{df}$

xerfcc $=$ xerfcc- $d x$

10 continue

if ( $a b s(d x)$. It. XACC) return

write $(*, *)$ 'MAXIT reached in xerfcc.'

return

end

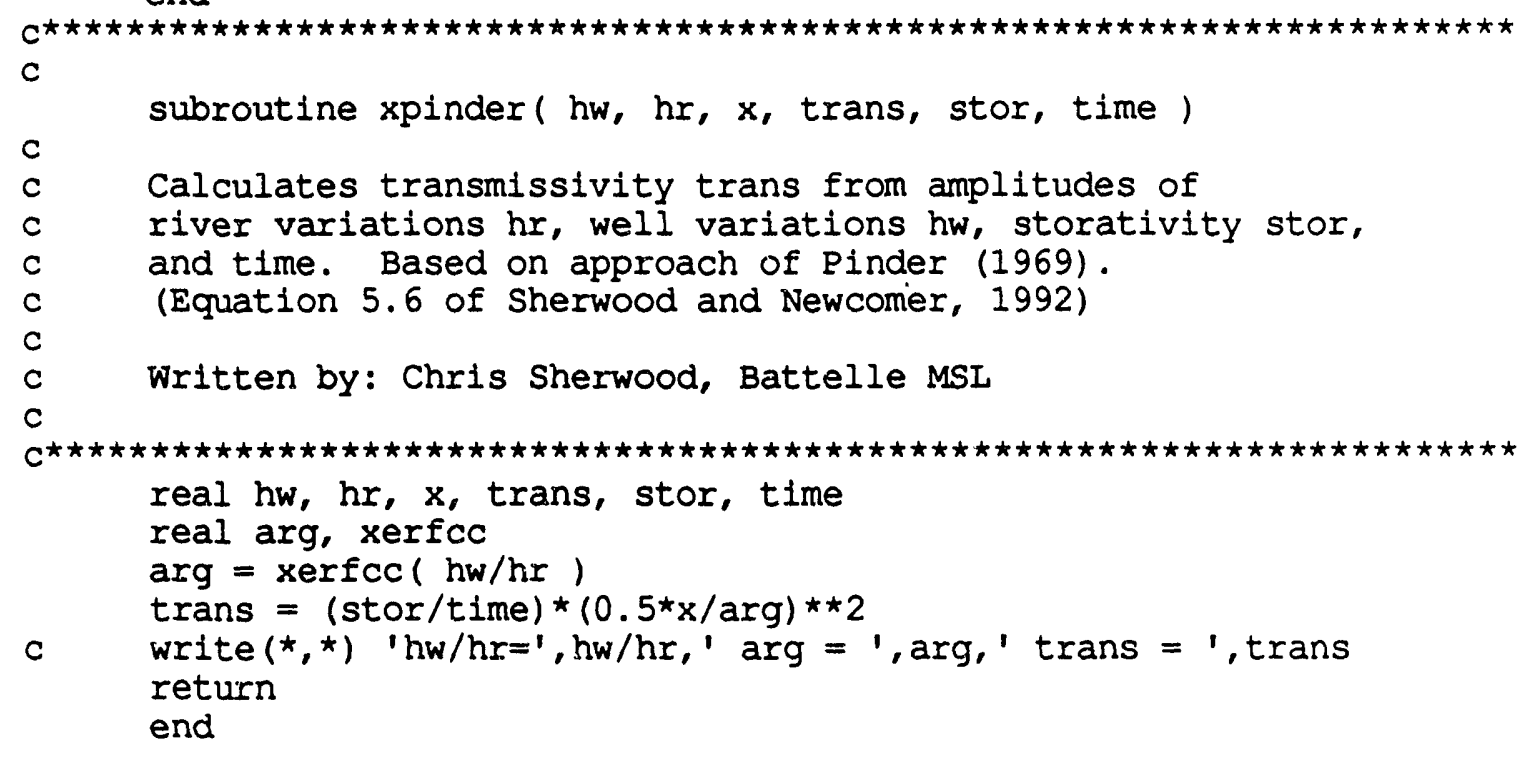



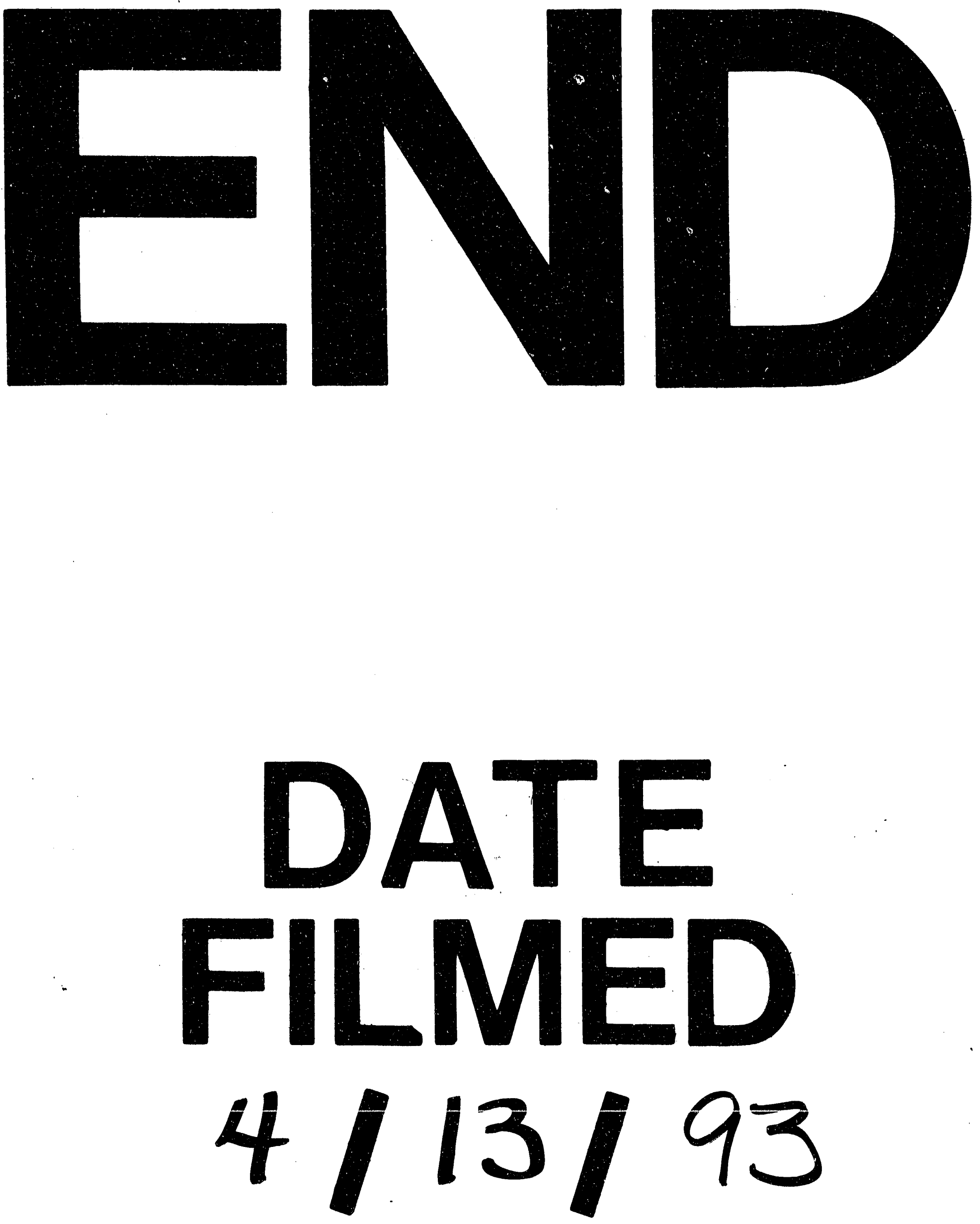

$f$ 
